\title{
Geology of El Misti volcano near the city of Arequipa, Peru
}

\author{
Jean-Claude Thouret* \\ Anthony Finizola \\ UMR 6524-CNRS Laboratoire Magmas et Volcans, and Institut de Recherche pour le Développement, Université Blaise-Pascal, \\ 5 rue Kessler, 63038 Clermont-Ferrand cedex, France
}

Michel Fornari

IRD, UMR 6526-CNRS “Géosciences Azur," Faculté des Sciences, Université de Nice, Parc Valrose, 06108 Nice cedex 02, France

Annick Legeley-Padovani

Laboratoire de Géophysique Interne, Centre IRD Ile-de-France, 34 rue Henri-Varagnat, 93143 Bondy cedex, France

Jaime Suni

Instituto Geofísico del Perú, Oficin Regional, Urbanización La Marina B19, Cayma, and Universidad Nacional San Agustín, Arequipa, Perú

Manfred Frechen

Centre for Environmental Change and Quaternary Research, GEMRU, Francis Close Hall, Swindon Road, Cheltenham GL50 $4 A Z, U K$

\section{ABSTRACT}

Approximately 750000 people live at risk in the city of Arequipa, whose center lies 17 km from the summit (5820 masl [meters above sea level]) of the active El Misti volcano. The composite edific comprises a stratovolcano designated Misti 1 (ca. 833$112 \mathrm{ka}$ ), partially overlapped by two stratocones designated Misti 2 and Misti 3 (112 ka and younger), and a summit cone Misti 4 (11 ka and younger).

Eight groups of lava flow and pyroclastic deposits indicate the following volcanic history. (1) Three cones have been built up since ca. $112 \mathrm{ka}$ at an average eruptive rate of $0.63 \mathrm{~km}^{3} /$ k.y. (2) Several episodes of growth and destruction of andesitic and dacitic domes triggered dome-collapse avalanches and block-and-ash-flows Deposition of these flow alternated with explosive events, which produced pyroclastic-flo deposits and tephra-fall and surge deposits. (3) Nonwelded, dacitic ignimbrites may reflec the formation of a $6 \times 5 \mathrm{~km}$ incremental caldera collapse on Misti 2 (ca. 50000 and $40000 \mathrm{yr}$ B.P.) and a $2 \times 1.5 \mathrm{~km}$ summit caldera on Misti 3 (ca. 13700 to 11300 yr B.P.). (4) Tens of pyroclastic flow and

\footnotetext{
*E-mail: thouret@opgc.univ-bpclermont.fr.
}

at least 20 tephra falls were produced by Vulcanian and sub-Plinian eruptions since ca. $50 \mathrm{ka}$. On average, ash falls have occurred every 500 to $1500 \mathrm{yr}$, and pumice falls, every 2000 to 4000 yr. (5) Misti erupted relatively homogeneous andesites and dacites with a few rhyolites, but Misti 4 reveals a distinct mineral suite. Less evolved andesites prevail in scoriaceous products of group 4-1 including historical ash falls. Scoriae of Misti 4 and the ca. 2300-2050 yr B.P. banded pumice commonly show heterogeneous textures of andesite and rhyolite composition. This heterogeneity may reflec changes in physical conditions and magma mixing in the reservoir. (6) Deposits emplaced during the Vulcanian A.D. 14401470 event and the sub-Plinian eruption(s) at ca. 2050 yr B.P. are portrayed on one map. The extent and volume of these deposits indicate that future eruptions of El Misti, even if moderate in magnitude, will entail considerable hazards to the densely populated area of Arequipa.

\section{INTRODUCTION}

El Misti is one of the seven potentially active volcanoes of the Central Andean volcanic zone of south Peru (de Silva and Francis, 1991). The Pleistocene volcanic range parallels the $\mathrm{N} 120^{\circ}$-trending boundary of the Western Cordillera, oblique to the $\mathrm{N} 80^{\circ}$ convergence of the Nazca plate along the Peruvian margin (Fig. 1). Straddling the south slope of the Cordillera Occidental and the north edge of the Arequipa depression, El Misti is the most recently active edific of a cluster of Pleistocene volcanoes, which includes the dormant Chachani compound volcano, $15 \mathrm{~km}$ to the northwest, and the extinct Pichu Pichu compound volcano, $20 \mathrm{~km}$ to the southeast (Fig. 1; Thouret et al., 1995; Thouret, 1999b). El Misti lies within a complex extensional and strike-slip tectonic setting of four groups of faults: the active, west-northwest-trending, normal-slip, en echelon Huanca fault, dipping southwest with a moderate left-lateral strikeslip component, which offsets the probably inactive north-, northeast-, and north-northwesttrending normal- and strike-slip faults. The northeast-trending faults and the inherited north-trending compressive faults have guided the formation of the 1-km-deep Río Chili canyon that drains the Cordillera Occidental toward the Arequipa tectonic basin at 2300 masl.

Eruptive activity at El Misti represents an impending threat for the 750000 inhabitants of Arequipa, Peru's second-largest city, cen- 


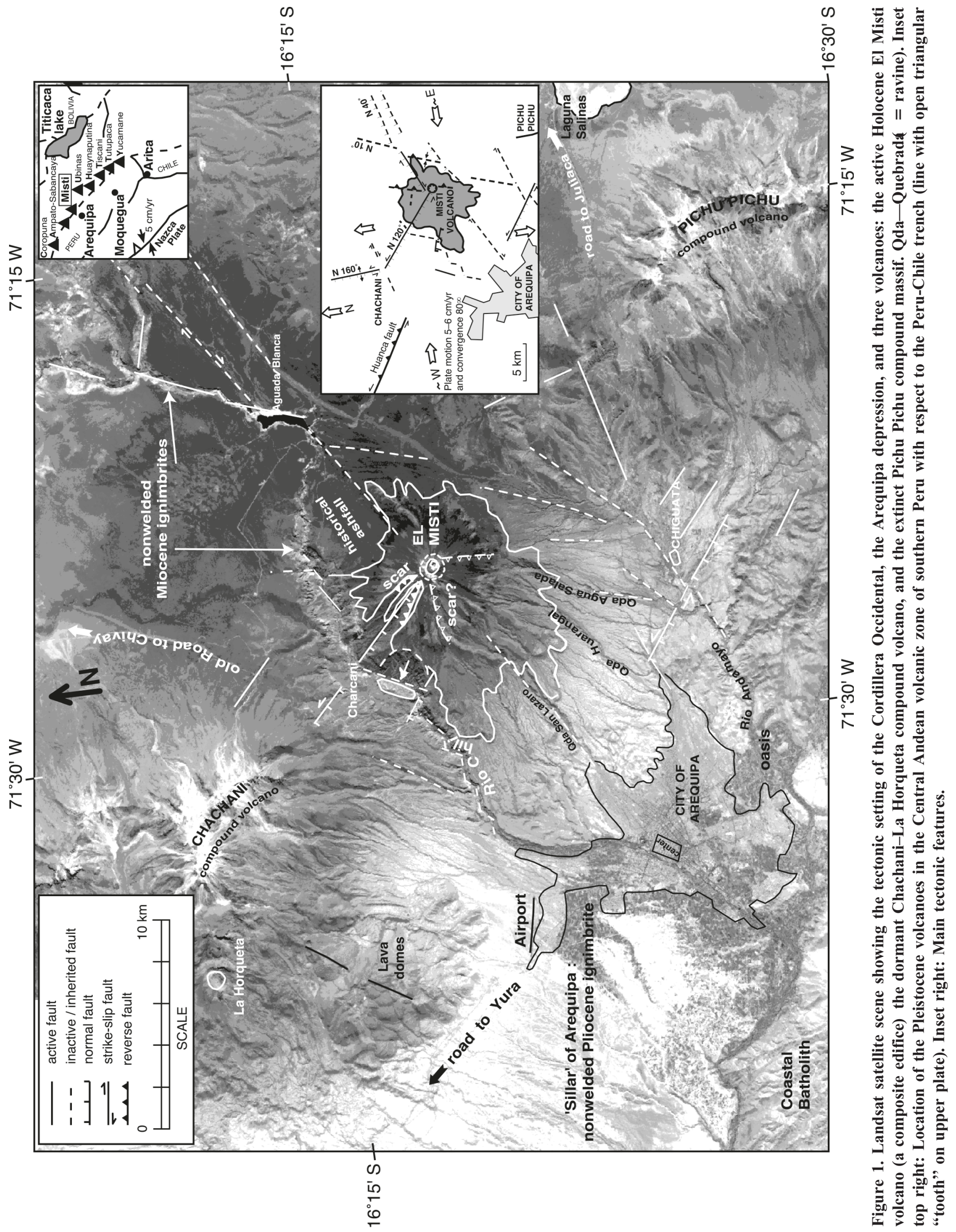


tered at 2300 masl and situated only $17 \mathrm{~km}$ to the southwest and $3.5 \mathrm{~km}$ lower in elevation than the volcano summit. Arequipa was founded in 1540 on the bank of the Río Chili at an oasis but remained small until 1940 (when its population was 86000 ). The population of Arequipa was 677000 in 1995 and since then has grown annually by as much as $5.5 \%$ (INEI-ORSTOM, 1998). Settlements now occupy two-thirds of the oasis area and the volcaniclastic fans that Quebradas (= ravines) San Lazaro and Huarangal have formed on the southwest ring plain of El Misti (Fig. $2 A)$. Since 1980 , the city has spread out upstream within $13 \mathrm{~km}$ of the summit near the quebradas that drain the southwest flank of the volcano, as well as west and east of the oasis. At least 220000 people live at risk from pyroclastic flows lahars, and flood on the fans and near quebradas. Of these, 50000 people live in suburbs along the Quebradas Huarangal and San Lazaro, and 170000 people live in the northeastern neighborhoods and in the town of Chiguata, $11 \mathrm{~km}$ south of the summit (Fig. 1).

Our geologic study was prompted by a joint research program (1995-1999) led by Institut de Recherche pour le Développement de France Hand Instituto Geofísico del Perú. Before our study, work on Ph.D. theses had addressed the stratigraphy of the Misti volcanic deposits (Macedo, 1994; Legros, 1998; Suni, 1999). Petrologic data were obtained by Lefèvre (1979), Legendre (1999), and one K-Ar date on a Misti lava flo was published by Kaneoka and Guevara (1984). The aim of this paper therefore is to determine (1) the geologic and volcanic setting of the Misti volcano, (2) the stratigraphy and chronology of the recent deposits of El Misti, based on geologic mapping and stratigraphic sections, and (3) the extent of the most recent tephra that has been erupted toward Arequipa.

\section{STRATIGRAPHY AND ERUPTION HISTORY}

El Misti comprises two edifices an eroded stratovolcano termed "Misti 1" partly overlapped by pristine stratocone edifice termed "Misti 2," "Misti 3," and "Misti 4" (Figs. $2 \mathrm{~A}$ and 3-5). The edifice have been built on top of "pre-Misti" volcaniclastic sediment (VS0 in Fig. 4) that unconformably overlies nonwelded rhyodacitic ignimbrites (Figs. 2B and 3-5), inaccurately termed "sillars" (Barker, 1996). The ignimbrites, which are $\geq 300 \mathrm{~m}$ in thickness in the Río Chili canyon (Fig. 2B; NI0 in Fig. 4) were emplaced as early as ca. 13.8 to $13.1 \mathrm{Ma}\left({ }^{40} \mathrm{Ar}-{ }^{39} \mathrm{Ar}\right.$, Fig. 6, col. B; Ta- ble 1; see also Data Repository ${ }^{1}$ ); the youngest "white sillar" of Arequipa yielded a fission track age of ca. 2.4 Ma (Vatin-Pérignon et al., 1996).

\section{Pre-Misti and Misti 1 Stratovolcano}

Misti 1 (ca. 833 to $>112$ ka; Figs. 3-6) consists of andesite lava flow as long as 9 $\mathrm{km}$ interbedded with thin volcaniclastic sediment and nonwelded ignimbrites, totaling $\geq 400 \mathrm{~m}$ in thickness. Above the Neogene ignimbrites, one lava flo at the base of Misti 1 was dated at ca. 833 ka (Fig. 2A; LF1 in Fig. 4; Fig. 6, col. B; Table 1; Data Repository).

\section{Subdued, Distal Debris-Avalanche Deposit}

El Misti shows no failure scar, except on the eroded west-northwest flan and possibly on the south flank however, two debris-avalanche deposits are found around El Misti (Figs. 2A, 3, and 4). The older deposit appears as DA0 in Figure 4.

To the southeast as far as $25 \mathrm{~km}$ away from the Misti summit, distal debris-avalanche deposits form hummocks $\geq 100 \mathrm{~m}$ thick in an $\sim 100 \mathrm{~km}^{2}$ area of the Arequipa basin and onto the west flan of the extinct Pichu Pichu volcano. The mixed and debris-block facies (after Glicken, 1991) of the hummocks are lithologically diverse and hydrothermally altered (Fig. 2C). The subdued hummocky topography, higher in elevation in the area of Río Andamayo (Fig. 4), has been interpreted to be the result of flan failures of the extinct Pichu Pichu volcano (Legros, 1998). However, major element, trace element, and rare earth element compositions of lava clasts (Legendre, 1999) from the debris-avalanche deposits are similar both east and south of Misti but differ from the lavas of Pichu Pichu. The Nb/La, Th/La, and $\mathrm{Yb} / \mathrm{La}$ ratios of most of the debris-avalanche clasts (Legendre, 1999) are similar to the ratios in Misti's lavas, and this result points toward El Misti as the probable source. However, we do not know whether the flan failure, which produced the subdued, distal debris-avalanche deposits, occurred on a preMisti volcano or on Misti 1.

\section{Proximal, Nonweathered Debris- Avalanche Deposit}

The second debris-avalanche deposit at least $50 \mathrm{~m}$ thick found around El Misti covers

GSA Data Repository item 2001135, description of $\mathrm{Ar} / \mathrm{Ar}$ and TL dates and of geochemistry and minerals in lavas and tephras, is available on the Web at http://www.geosociety.org/pubs/ft2001.htm. Requests may also be sent to editing@geosociety. org. the south and southwest flank (an $\sim 40 \mathrm{~km}^{2}$ area) as far as $12 \mathrm{~km}$ to the southwest (Quebrada San Lazaro) and south (Quebrada Mariano Melgar) of the summit. The deposit forms flat-toppe terrain in which nonweathered, dacitic and rhyolitic debris-block facies fille topographic lows that channeled the avalanches on the south flank Deposits with similar debris-block facies and composition crop out also on the steep northwest flan of Misti in the Río Chili canyon (DA1 in Fig. 4). These deposits overlie nonwelded dacitic ignimbrites of Misti 1 (El Chilcal, Fig. 3) and are overlain by the ca. 112 ka lava flow of Misti 2. Thus, a flan failure on Misti 1 may have triggered the proximal, nonweathered debris-block facies avalanche.

\section{Misti 2-4 Stratocones Formed Since ca. 112 ka}

The Misti 2, 3, and 4 stratocones (112 ka and younger) consist of stubby lava flow and pyroclastic debris as thick as $2.2 \mathrm{~km}$ (Fig. 5). Pyroclastic debris shed by the cones moved downslope 10 to $25 \mathrm{~km}$ away from the summit; the debris mantled the slopes of El Misti and formed an extensive volcaniclastic ring plain with an area of $\sim 200 \mathrm{~km}^{2}$. The deposits include two fans (Quebradas San Lazaro and Huarangal, Figs. 2A and 3) upon which the city of Arequipa has grown. Composite stratigraphic sections show seven groups of lava and pyroclastic-flo , -fall, and -surge deposits. The sections are amplifie by fiel mapping, lithologic and petrologic study, and forty ${ }^{40} \mathrm{Ar}-{ }^{39} \mathrm{Ar}$, thermoluminescence (TL), and ${ }^{14} \mathrm{C}$ dates (Fig. 6, col. A; Tables 1 and 2; Data Repository). The groups record the growth and destruction of Misti 2-4 during since 112 ka.

\section{Misti 2 Stratocone}

Group 2-1, ca. 112-70 ka. The stratigraphically basal group consists of stubby lava flow and block-lava flow of domes that form steep fronts and a break in slope at the base of Misti 2 (3000-3800 masl) toward the south, southwest, east, and northeast (Fig. 3; LF2 in Fig. 4; Fig. 6, col. B; Table 1). Extrusive activity occurred between ca. 110 and 70 ka (Fig. 6). Group 2-1 also includes blockand-ash flow and scoriaceous and pumiceous pyroclastic-flo deposits. The succession is interbedded with lava flows which have built up Misti 2 as high as 4000 to 4500 masl (Figs. 4 and 5).

Group 2-2, ca. 70-50(?) ka. Group 2-2 deposits are andesite and dacite blocks 10 to 

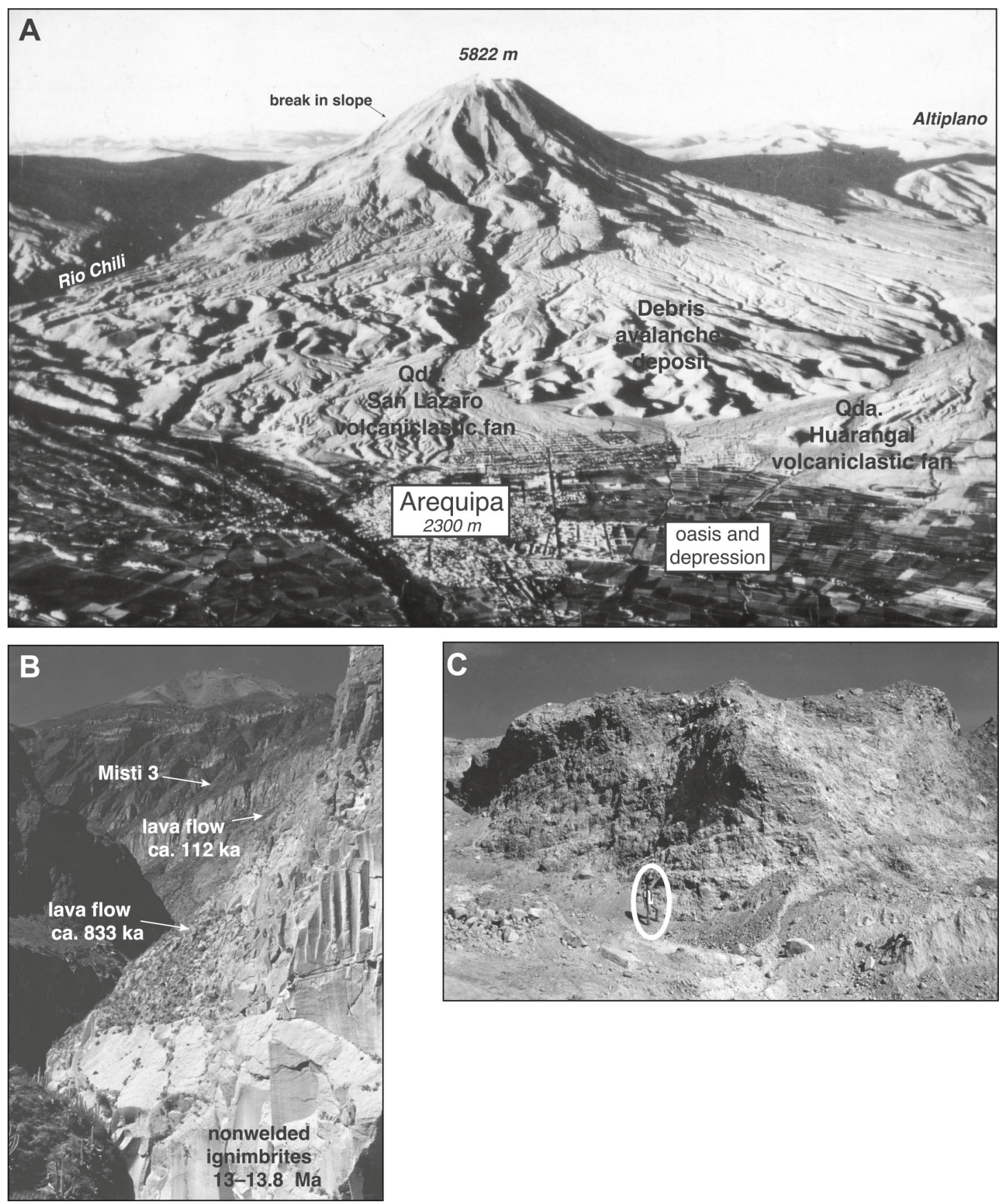

Figure 2. (A) El Misti stratovolcano looking northeast over the depression and town of Arequipa in 1940 (courtesy of I. Parodi). Break in slope at $\sim \mathbf{4 4 0 0}$ masl coincides with a structural boundary. (B) "Pre-Misti" nonwelded ignimbrites and lava flow of Misti 1, in the 1-km-deep Río Chili canyon, overlain by the 2.2-km-thick cones of Misti 2, Misti 3 (shown), and Misti 4. (C) Mixed and debris-block facies of a debris avalanche $14 \mathrm{~km}$ south of the Misti summit (road to Chiguata).

$20 \mathrm{~m}$ thick, found as far as $11 \mathrm{~km}$ down valley from the vent in the Quebradas Agua Salada, Pastores, and Huarangal (DC2 in Fig. 4; Fig. 7, A and B; and Fig. 8, cols. 1-3). The matrixpoor deposit containing dome blocks indicates collapse of voluminous domes that had grown on the firs stratocone at 3800-4500 masl.
Prismatically jointed blocks indicate that the dome-collapse deposits were emplaced hot.

Interbedded with group 2-2 andesite (as well as with group 2-3 rocks, described next), greenish scoriaceous and pumiceous-flo and -fall deposits mantle the southeast flan of Chachani volcano and parts of the southwest flan of Misti to depths of $10 \mathrm{~m}$ (Fig. 7B and Fig. 8, cols. 2 and 6). The dark mafi andesite $\left(53 \%-55 \% \mathrm{SiO}_{2}\right)$ scoriaceous lapilli from Chachani contrasts with the yellowish, andesite-dacite pumice of Misti $\left(57 \%-66 \% \mathrm{SiO}_{2}\right)$. Bread-crust bombs in scoriaceous deposits interbedded with glacier and laharic deposits 


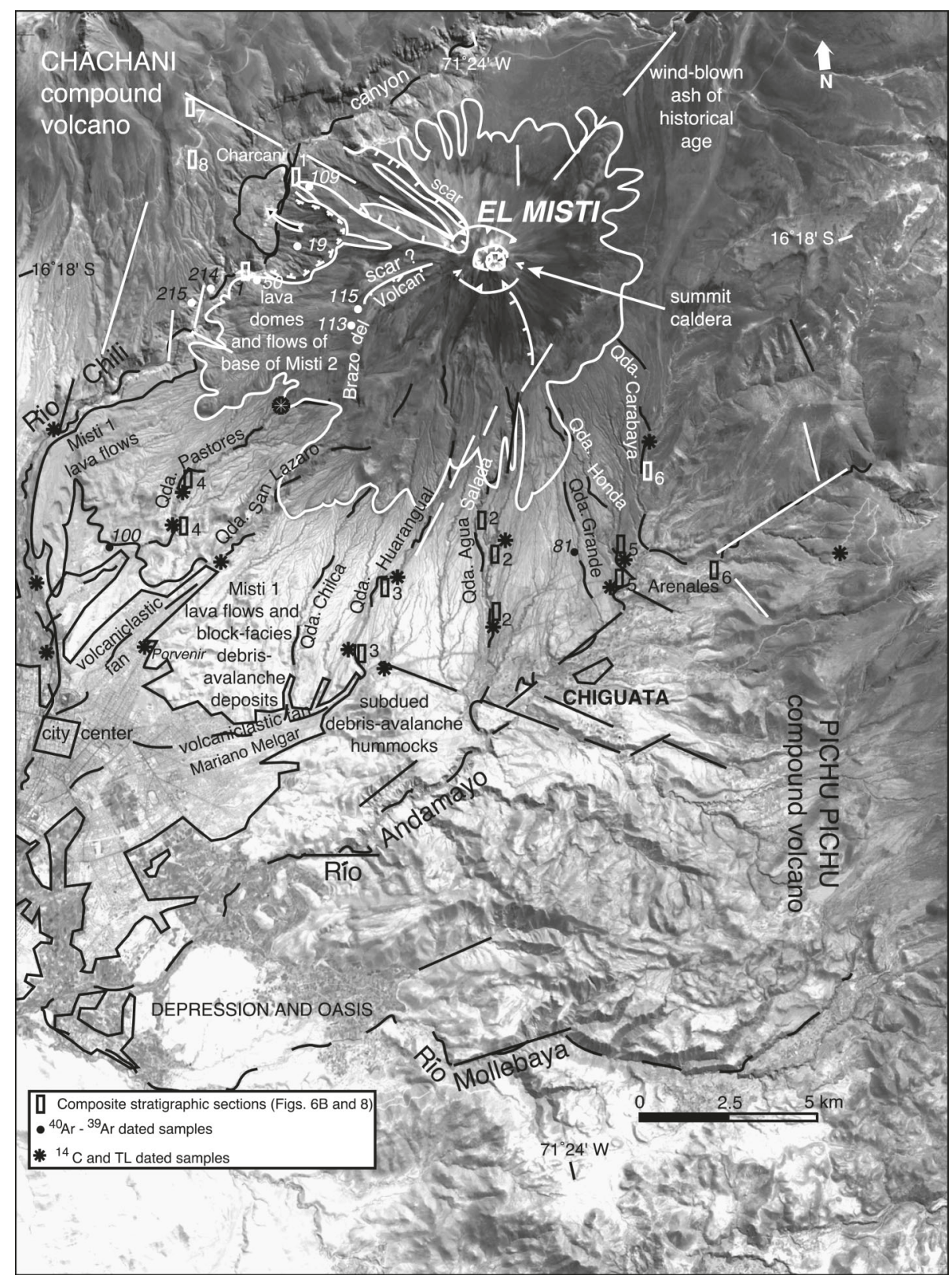

Figure 3. SPOT satellite scene (1991) showing EI Misti volcano, the city of Arequipa, the main drainage channels, and important geologic features of the volcano. Qda-Quebrada (= ravine).

above 3600 masl suggest hydromagmatic interactions possibly during the firs Last Glacial Maximum ( $\geq 43000$ yr B.P. according to Seltzer, 1990). (Note that in the Peruvian Andes, the second Last Glacial Maximum occurred between 24000 and 12000 yr B.P..)

Stratigraphic sections in quebradas on the south flan of Misti show streamflo and lahar deposits $10-20 \mathrm{~m}$ thick intercalated between groups $2-2$ and $2-3$. The volcaniclastic deposits unconformably overlie group 2-2 and/or the greenish deposits of Chachani. The unconformably on block-lava flow and domes of Misti 2 (Figs. 2A, 3, and 4).

2. Nonwelded ignimbrites of $3-5 \mathrm{~km}^{3}$ bulk volume (NI2 in Fig. 4; area is $>100 \mathrm{~km}^{2}$ and the ignimbrite deposits are $30-40 \mathrm{~m}$ thick on average) are found on the southwest, south, and southeast flank of the volcano; these form groups 2-3A and 2-3B (Fig. 2A; Fig. 6, col. A). Pumiceous and lithic pyroclastic-flo deposits topped by dacite pumice cobbles (Quebrada Huarangal, Fig. 7A) reflec largescale pyroclastic eruptions that may have led to the formation of an incremental caldera collapse. On the basis of ${ }^{14} \mathrm{C}$ dating, the $2-3 \mathrm{~A}$ subgroup erupted at ca. $50000-43000 \mathrm{yr}$ B.P. and the 2-3B subgroup erupted at ca. 40000 yr; thus, two distinct explosive episodes may have emplaced the ignimbrites (Fig. 6, col. A; Fig. 8, cols. 1-4; Table 2).

3. A structural boundary $4400 \pm 300$ masl is inferred from geoelectric self-potential (SP) measurements. The method consists of measuring differences in electric potentials between two electrodes. Differences in electric potentials are related to flui circulation within active volcanoes. The SP method aims to outline the extent of hydrothermal systems to reveal structural boundaries such as a buried caldera (e.g., Zablocki, 1976; Jackson and Kauahikaua, 1987). The SP map of Misti superimposed on a digital elevation model (DEM; Fig. 9) shows an SP minimum (with a low of $4.2 \mathrm{~V}$ [volts] in magnitude) that connects in a roughly rectangular shape measuring $6 \times 5 \mathrm{~km}$. This SP minimum divides the stratocone into (1) the lower half with negative correlation between SP values and elevation and (2) the upper half with positive correlation. This pattern, common on active volcanoes, is interpreted to be the result of electrofiltratio by downward flo of vadose water on the lower flank and upward flo of hydrothermal fluid on the upper flanks Hence, the cone shows two distinct areas: hydrogeologic and hydrothermal (Fig. 10). The upper limit of the hydrogeologic zone is located at the foot of Misti 3. The SP low appears to outline a structural boundary, interpreted as rims of large craters or of an incrementally formed caldera, that prevents the hydrothermal system from growing laterally. A $100^{\circ}$-trending normal fault dipping $70^{\circ}$ toward the summit parallels the presumed boundary to the north, and $10^{\circ}-40^{\circ}$-trending faults parallel the presumed structural boundary to the west and east (Figs. 1, 4, and 9).

Two additional methods reveal a discontinuity supporting the hypothesis of a structural boundary at $\sim 4400$ masl. A morphometric analysis of the slopes and shape of the stra- 


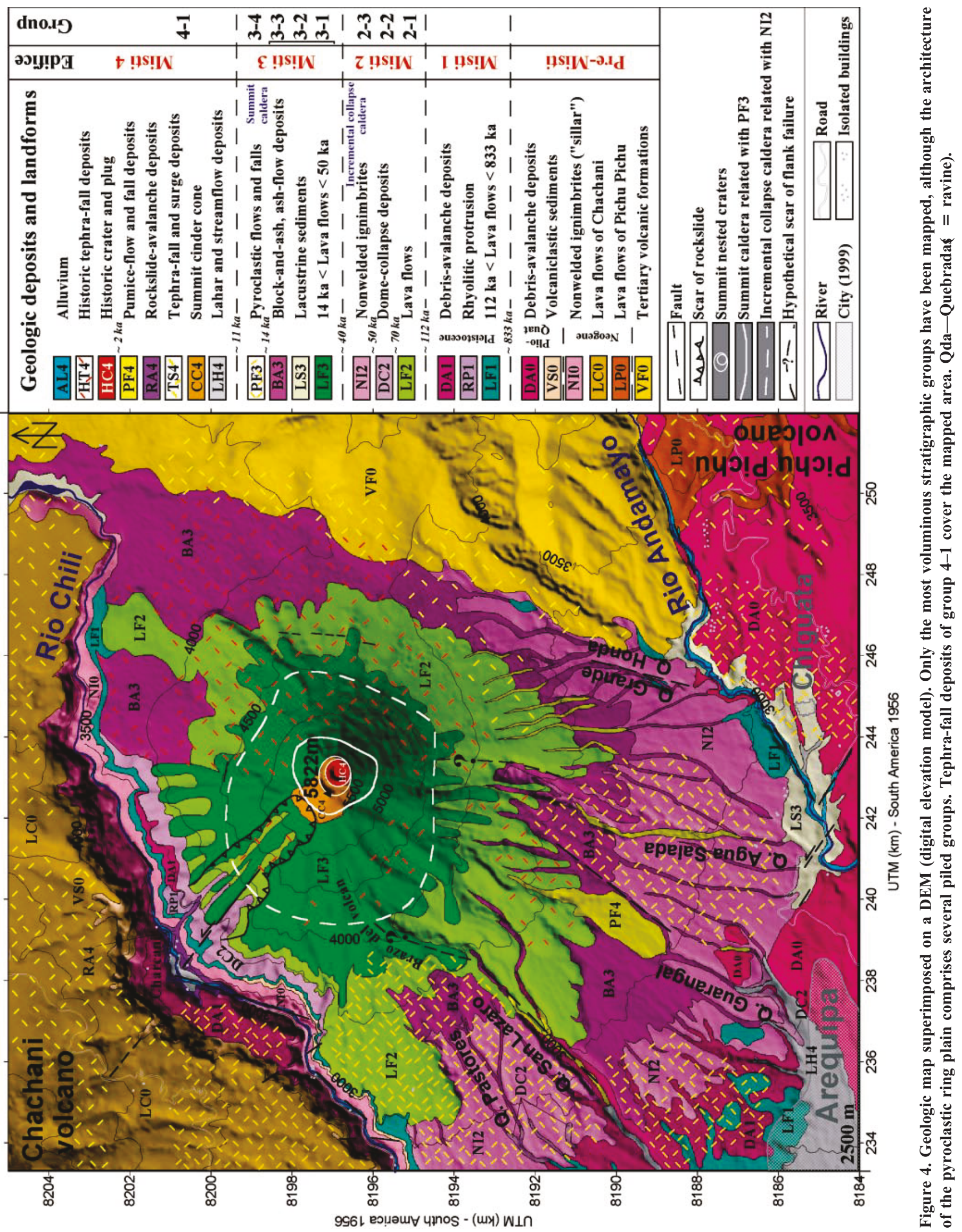




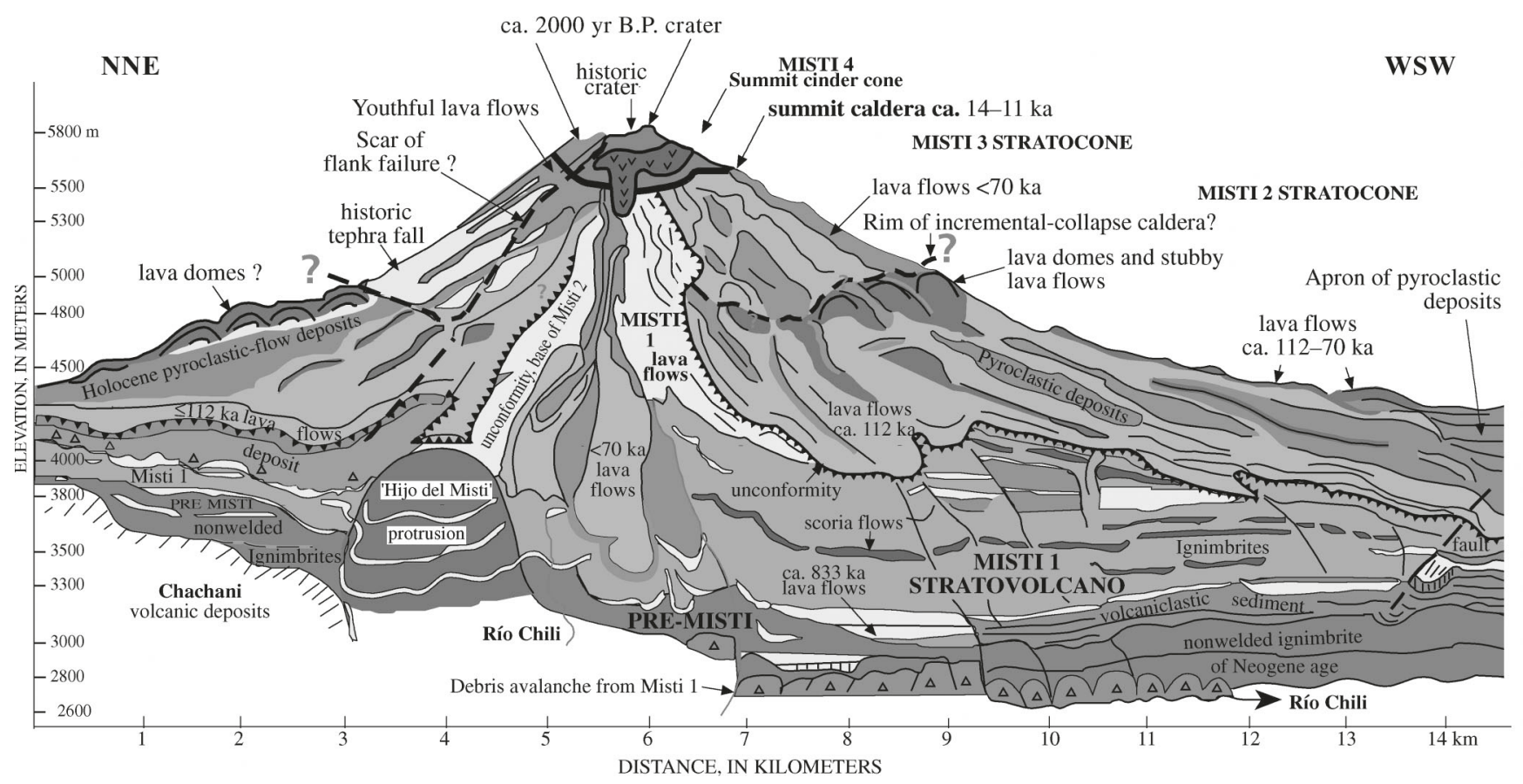

Figure 5. Schematic geologic cross section of the north to southwest flank of EI Misti volcano (east bank of the Río Chili canyon), showing the pre-Misti bedrock, the Misti 1 stratovolcano, the Misti 2 and 3 stratocones, and the Misti 4 summit cone. The presumed incremental caldera on Misti 2 and the summit caldera on Misti 3 are outlined.

tocone based on a DEM shows a major discontinuity at 4400 masl (García-Zuñiga and Parrot, 1998). A controlled-source audio-magnetotelluric method, carried out by K. Pistre (2000, personal commun.), aimed at obtaining resistivity values as a function of depth on El Misti. A large $(100 \mathrm{~m})$ zone of low resistivity, in the range of $10-25 \Omega \cdot \mathrm{m}$, coincides with the self-potential transition zone between the hydrogeologic and hydrothermal areas. Mineralization and argillization due to circulation of hydrothermal fluid along the structural boundary may explain why resistivity is very low in the transition zone.

\section{Misti 3 Stratocone}

Misti 3 was built up of lava flow and domes (LF3 in Fig. 4; Fig. 6, col. A; Table 2) between the elevations of $\sim 4400$ and 5600 masl. The eruptions were probably after 50000 but before $14000 \mathrm{yr}$ B.P., a period that overlapped the formation of groups 3-1 to 3-3.

Group 3-1, ca. 36-31 ka. To the southwest and southeast, a thick pile of dacitic ash-flo deposits and tephra-fall deposits forms group 3-1 (BA3 in Fig. 4; Figs. 7B and 8, cols. 2 and 5). Charcoal in soil at the base of group $3-1$ yielded ${ }^{14} \mathrm{C}$ ages of ca. $34000-33000 \mathrm{yr}$ B.P. (Table 2) in and beneath the ignimbrites (Quebrada Honda-Grande, Fig. 8, cols. 2 and 5). Radiocarbon dates on ash-flo deposits in group 3-2 indicate that the top of the dacitic group is older than ca. 31200 yr B.P. (Fig. 8, col. 5). These pyroclastic deposits at least 1.5 $\mathrm{km}^{3}$ in volume reflec a large explosive episode that may have enlarged the craters or the probable incremental-collapse caldera on Misti 2. On the south-southeast flan of El Misti, yellowish, dacitic pumice-flo , and tephra-fall deposits that overlie one dacitic lava flo are interbedded with groups 2-3 and 3-1. A pumice cobble from one flo deposit yielded a TL age of $36.1 \pm 6.8 \mathrm{ka}$ (Fig. 8, col. 3; Table 1).

Group 3-2, ca. $\leq \mathbf{3 0 - 2 5}$ ka. The voluminous group 3-2, containing 30-50-m-thick dacitic block-and-ash-flo and lithic pyroclastic-flo deposits, mantles an extensive area on the south-southwest flan (BA3 in Fig. 4). The pyroxene- and amphibole-bearing andesite succession includes pumice-fall layers 20-40 $\mathrm{cm}$ thick as far as $12 \mathrm{~km}$ from the summit (Fig. 6, col. A; Fig. 8, cols. 1-3). Block-andash-flo deposits record episodes of growth and destruction of domes that have built up Misti 3 between $\leq 30000$ and ca. $25000 \mathrm{yr}$ B.P. (Fig. 6, col. A; Table 2). Yellow-greenish pyroclastic-flo and tephra-fall deposits 10 $15 \mathrm{~m}$ thick are interbedded with groups 3-2 and $3-3$ on the southeast flan of El Misti (Fig. 8, col. 5).

Group 3-3, ca. $\leq 25-20$ ka. An andesitic succession encompasses as much as fiv block-and-ash-flo units 5 to $20 \mathrm{~m}$ thick on the south flan (BA3 in Fig. 4; Fig. 8, col. 5).
These units suggest growth and destruction of domes of Misti 3 between ca. $\leq 25000$ and ca. 20000 yr B.P. (Table 2). The block-andash-flo deposits include pumice-fall deposits whose grain size and thickness increase toward the volcano's summit, thus showing Misti as the source. The youngest of the pumice-fall layers erupted at ca. $21 \mathrm{ka}$ (Fig. 8, col. 3 ); one pumice cobble from the second pumice-fall layer was dated at ca. $20.3 \mathrm{ka}$ (TL, Table 1). The most voluminous $\left(\leq 0.5 \mathrm{~km}^{3}\right)$ Plinian pumice-fall deposit of El Misti is 1 to $3 \mathrm{~m}$ thick at distances of $9-12 \mathrm{~km}$ west and southeast of the vent (Figs. 7C and 8, col. 6).

In the upper radial valleys, toward the top of group 3-3, debris-flo and stream-flo deposits are interbedded with block-and-ashflo and scoria-flo deposits including phreatomagmatic bombs. In U-shaped valleys probably carved by glaciers on the southeast flan of Chachani above 3600 masl, stratifie layers of ash with subrounded pumice were emplaced in water and probably formed terraces on the edge of former glacier tongues (Fig. 7C). Tephra deposits were likely reworked by meltwater from ice field that capped the Misti and Chachani summits during the second Last Glacial Maximum (between 24000 and 12000 yr B.P.; Seltzer, 1990).

Summit Caldera on Misti 3, Group 3-4, ca. 14-11 ka. Misti 3 was in turn truncated 
EDIFICE GROUP DATE SECTION INTERPRETATION
INTEN

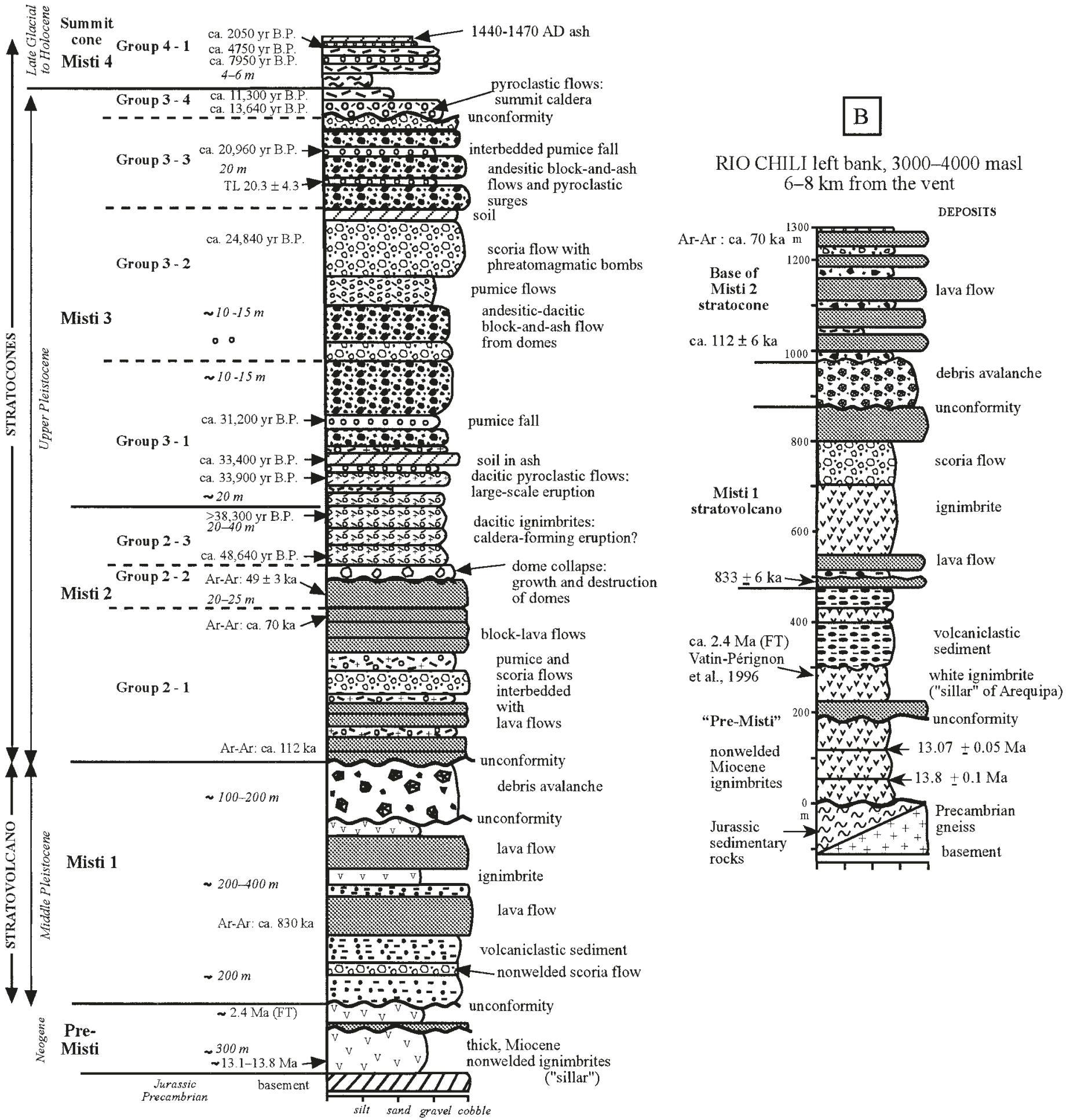

Figure 6. (A) Composite stratigraphic section of pre-Misti, Misti 1, and groups of Misti $2-4$ cones based on measured columns (located in Fig. 8). (B) Composite stratigraphic section on the left bank of the Río Chili canyon showing pre-Misti and Misti 1-2 deposits. 
TABLE 1. SELECTED ${ }^{40} \mathrm{Ar}-{ }^{39} \mathrm{Ar}$ AND TL AGES AT MISTI VOLCANO

\begin{tabular}{|c|c|c|c|c|c|c|c|}
\hline $\begin{array}{l}\text { Samples } \\
\text { number }\end{array}$ & & $\begin{array}{l}\text { Location } \\
\text { (in Fig. 3) }\end{array}$ & $\begin{array}{l}\text { Elevation } \\
(\mathrm{m})\end{array}$ & Edific & $\begin{array}{l}\text { Group } \\
\text { (ka) }\end{array}$ & & $\begin{array}{l}\text { Age } \\
\text { (ka) }\end{array}$ \\
\hline Mi 81 & Whole rock & Qda. Honda & 3250 & Misti 3? & Group 3-1? & 49 & \pm 3 \\
\hline Mi 115 & Whole rock & Brazo del Misti & 4400 & Misti 2 & Group 2-2 & 70 & \pm 3 \\
\hline Mi 113 & Whole rock & Brazo del Misti & 4000 & Misti 2 & Group 2-1 & 98 & \pm 3 \\
\hline Mi 109 & Whole rock & Rio Chili, Charcani V & 3600 & Misti 2 & Group 2-2 & 105 & \pm 2 \\
\hline Mi 50 & Whole rock & Pacheco torres Rio Chili & 3350 & Base of Misti 2 & Group 2-2 & 112 & \pm 6 \\
\hline Mi 100 & Whole rock & Rio Chili downstream Charcani I & 2800 & Base of Misti 1 & & 833 & \pm 6 \\
\hline Mi 214 & On biotite & Rio Chili canyon, Charcani III & 2800 & Pre-Misti ignimbrite & & 13.12 & $\pm 0.05 \mathrm{Ma}$ \\
\hline Mi 215 & On biotite & Rio Chili canyon, Charcani III & 2880 & Pre-Misti ignimbrite & & 13.8 & $\pm 0.1 \mathrm{Ma}$ \\
\hline \multicolumn{8}{|c|}{ Thermoluminescence on plagioclase in pumice } \\
\hline TL Mi 200b & & Huarangero dirt road & 2850 & & Group 3-3 & 20.3 & \pm 4.3 \\
\hline TL Mi 200 & & Qda. Huarangal & 2800 & & Group 3-1 & 36.1 & \pm 6.8 \\
\hline
\end{tabular}
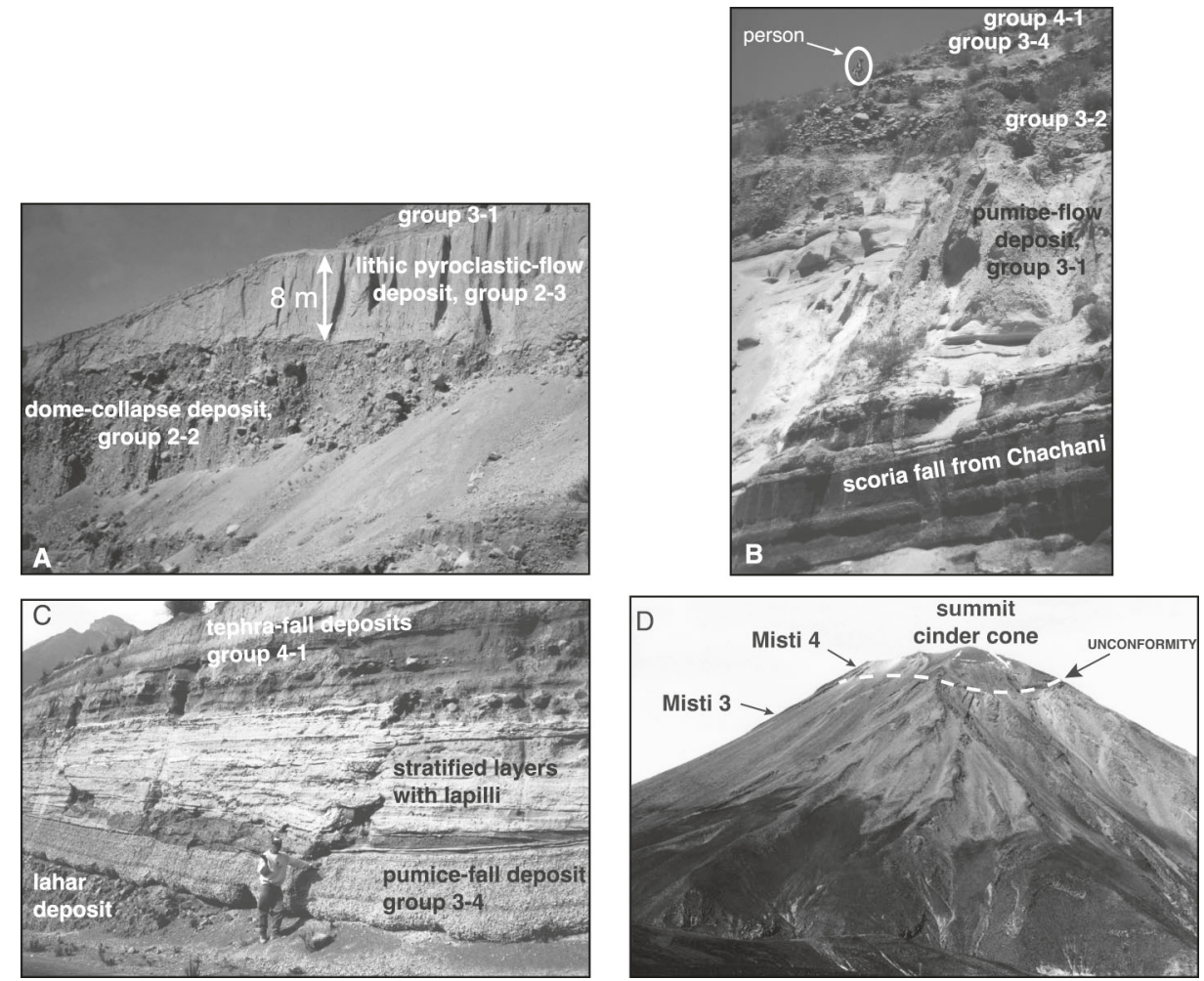

Figure 7. (A) Quebrada Huarangal section $11 \mathrm{~km}$ from the vent showing pyroclastic deposits of groups 2-2 and 2-3. (B) Section $20 \mathrm{~m}$ thick in Quebrada Pastores $9 \mathrm{~km}$ from the vent showing andesitic scoriaceous fall deposits of Chachani, overlain by pyroclastic deposits of groups 3-1, 3-2, 3-4, and 4-1. (C) Section $8 \mathrm{~km}$ west of the summit (road to Charcani, 3600 masl) showing a 1-m-thick pumice-fall deposit of group 3-4 above lahar deposits and overlain by stratifie layers of reworked ash and tephra-fall deposits of group 4-1. (D) Northwest flan of El Misti with unconformity surrounding the summit caldera at $\sim 5400$ masl.

by formation of a summit caldera $2 \mathrm{~km}$ across above the elevation of $5400 \mathrm{~m}$ (Figs. 3-5). Evidence for a summit caldera is threefold:

1. Cliffs of welded scoria-flo deposits on the west-northwest summit slope (at 5400 masl) and lava flow unconformably overlie steep lava flow of Misti 3 dipping to the west (Fig. 7D).

2. Pyroclastic-flo deposits of $\sim 1 \mathrm{~km}^{3}$ bulk volume (PF3 in Fig. 4; area $\sim 50 \mathrm{~km}^{2} \times 20$ $\mathrm{m}$ thickness) with interbedded pumice-fall and pyroclastic-surge beds $\left(\leq 0.5 \mathrm{~km}^{3}\right)$ form group 3-4 (Fig. 4). A voluminous, 1-m-thick pumice-fall deposit, $9 \mathrm{~km}$ west of the vent (Fig. $7 \mathrm{C}$ ), is stratigraphically beneath one of the thick scoria-flo deposits dated at ca. 13700 yr B.P. (Fig. 8, cols. 2 and 5). At the base of the interbedded pumice-fall deposits, group 3 4 also contains 10-20-cm-thick cross-bedded layers of gray lithic ash with oxidized frag- ments that form pinch-and-swell and dunelike features (Fig. 8, cols. 2, 4, and 6). These layers are interpreted as pyroclastic surges that traveled as far as $12 \mathrm{~km}$ south and southwest of the vent. The radiocarbon dates indicate that the deposits were emplaced in two explosive eruptions between ca. 13700 and 11300 yr B.P. (Fig. 6, col. A; Fig. 8, cols. 2 and 5; Table 2). These dacitic deposits may reflec caldera-forming eruptions.

3. An elliptical structural boundary $(2 \times$ $1.5 \mathrm{~km})$ is inferred from a secondary self-potential minimum $\sim 5400$ masl (Figs. 9 and 10). A morphometric analysis of the stratocone also reveals a structural discontinuity at 〜5400 masl (García-Zuñiga and Parrot, 1998).

Misti 4 Summit Cone, Group 4-1, $<11$ ka

The crescent-like summit is a cinder cone (CC4 in Fig. 4) designated Misti 4, which formed above the summit caldera of Misti 3 . Welded scoria-flo or fall deposits buried the west part of the caldera, but two nested craters were opened in the central and eastern areas of the caldera (Fig. 11A). The 950-m-wide crater, breached to the south, may have been formed during a ca. 2300-2050 yr B.P. explosive episode. The nested scoria-rimmed crater, $550 \mathrm{~m}$ across and $200 \mathrm{~m}$ deep, cut domes in historic time. It is blocked by an andesite plug, where fumarolic activity persists (Fig. 11B).

A 5-6-m-thick pile of tephra-fall deposits indicates that Misti 4 erupted tephra at least 10 times since $11000 \mathrm{yr}$ B.P. (TS4 in Fig. 4; Fig. 8, cols. 2 and 5). The tephra-fall beds are intercalated in scoriaceous ash-flo deposits on the southwest to southeast flanks Thin, cross-bedded, dune-like ash layers, interpreted as pyroclastic surges similar to those of group 3-4, traveled $8 \mathrm{~km}$ southeast toward Chiguata ( $\geq 6400 \mathrm{yr}$ B.P.) and $13 \mathrm{~km}$ southwest toward the Río Chili valley (ca. 5200 yr B.P.; Figs. 4 and 8, col. 4). Two pyroclastic-surge deposits were emplaced just before ca. 11300 yr B.P. and as recently as ca. $4750 \mathrm{yr}$ B.P. in what is 


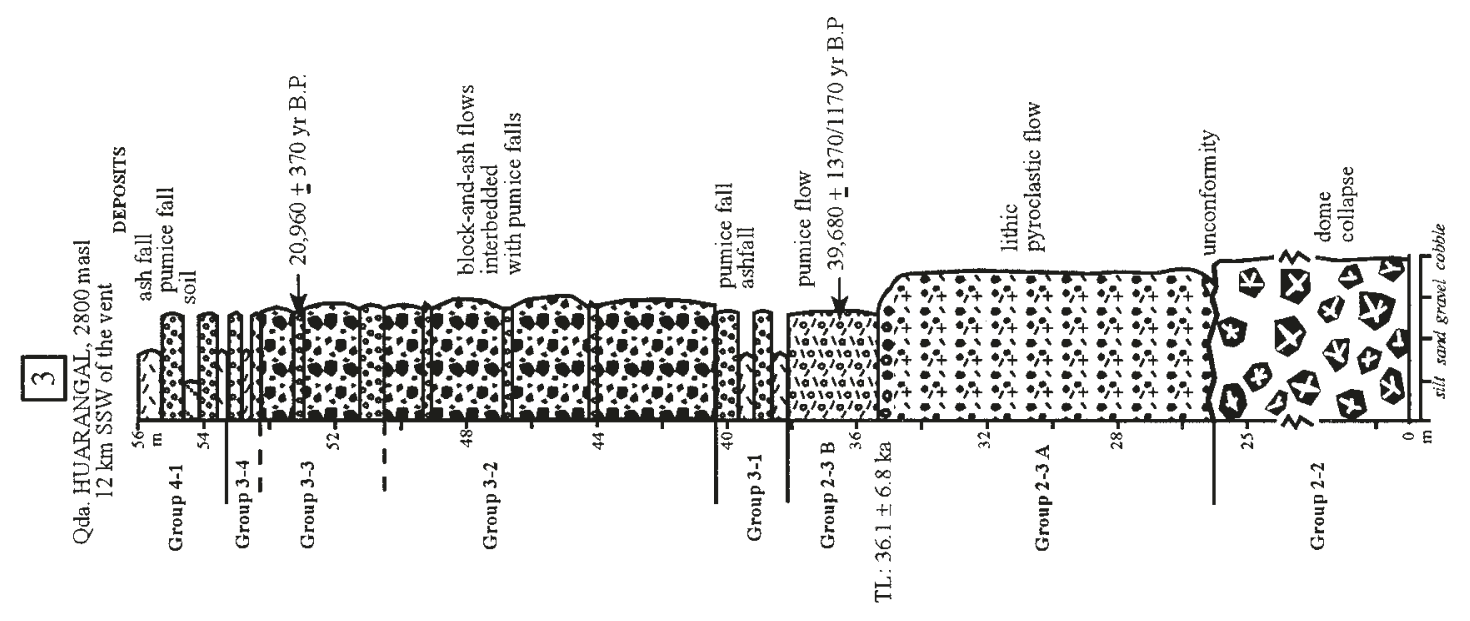

(1)
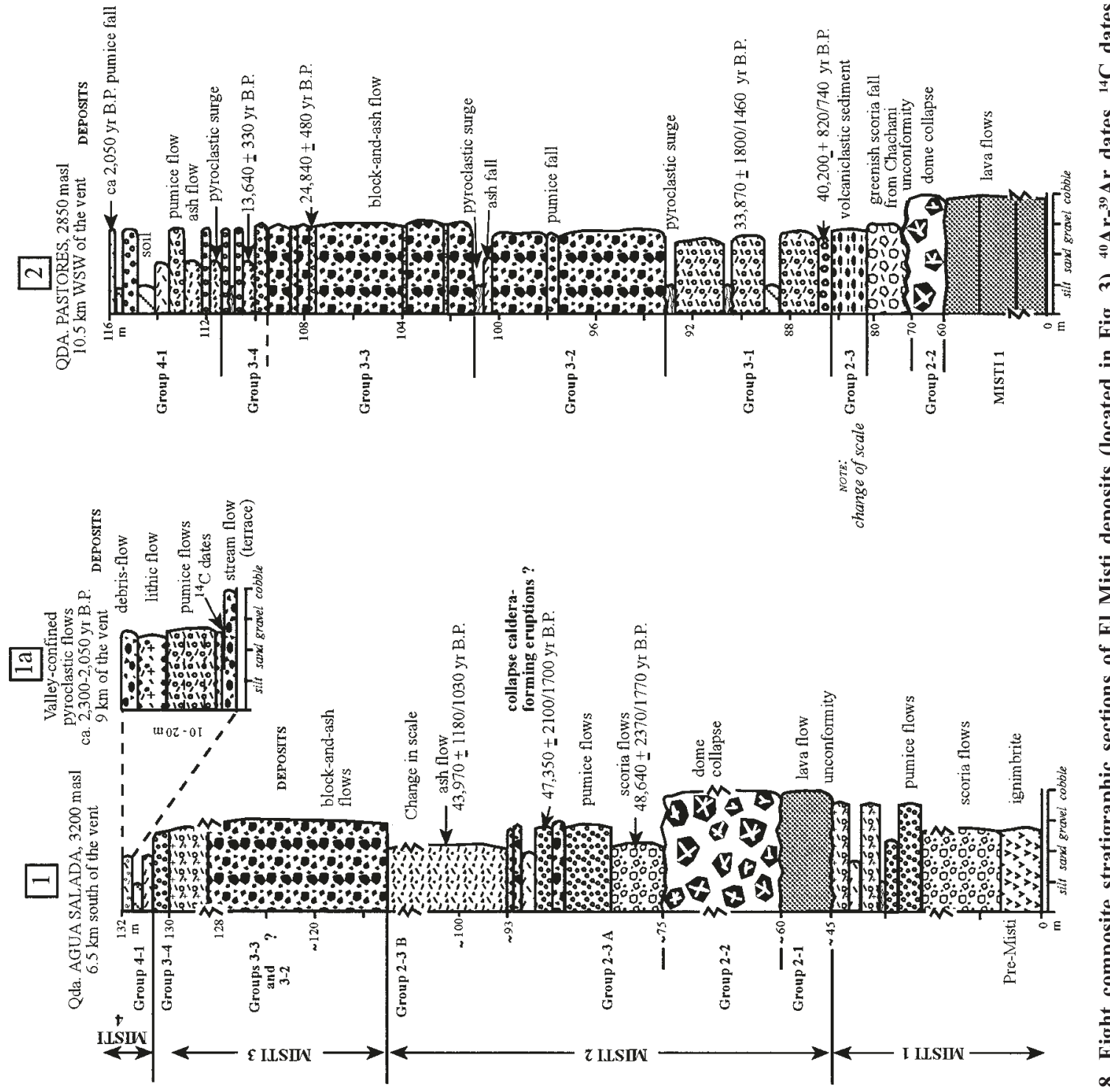

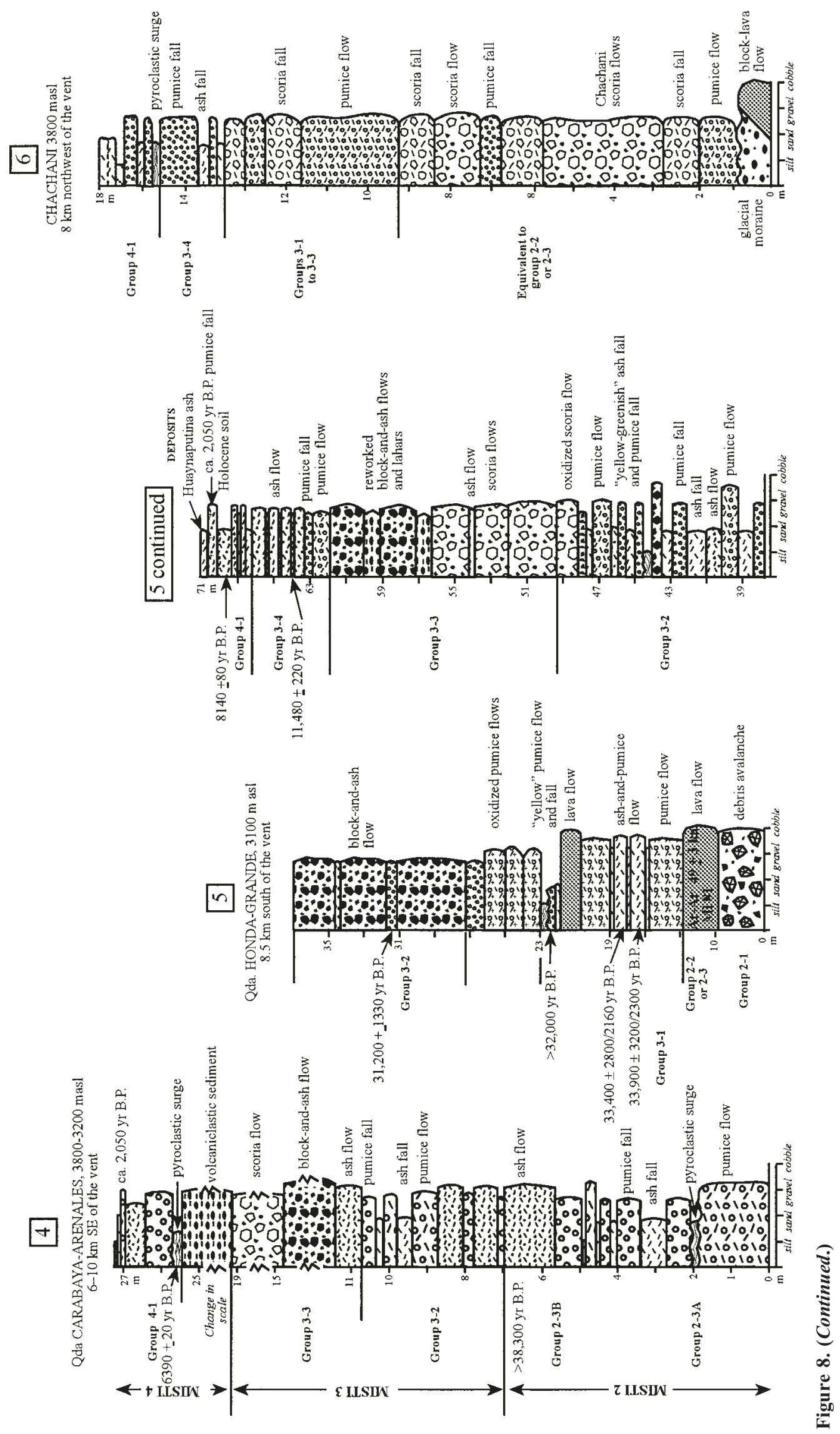
TABLE 2. LIST OF 14 C DATES

\begin{tabular}{|c|c|c|c|c|c|c|}
\hline $\begin{array}{l}\text { Sample } \\
\text { number }\end{array}$ & $\begin{array}{c}\text { Location } \\
\text { (Figs. 3, 5, and 10) }\end{array}$ & Material & Deposit & Group & $\begin{array}{l}{ }^{14} \mathrm{C} \text { age } \\
\text { (yr B.P.) }\end{array}$ & $\begin{array}{l}\text { Calibrated age } \\
\qquad(1 \sigma)\end{array}$ \\
\hline GrN-23966 & $\begin{array}{l}\text { Academia Yanahuara, Río } \\
\text { Chili, Arequipa }\end{array}$ & Charcoal & Lahar & Middle terrace & $520 \pm 25$ & $1407-1428$ cal A.D. \\
\hline GrN-23965 & Río Chili, Chocita & Charcoal & Silt & Low terrace & $340 \pm 40$ & 1488-1633 cal A.D. \\
\hline GrN-23888 & $\begin{array}{l}\text { Qda. Huarangal entrada } \\
\text { Mariano Melgar }\end{array}$ & Charcoal & Streamflo & Volcaniclastic fan & $13650 \pm 300 / 290$ & \\
\hline GrN-22163 & Qda. Huarangal arriba & Organic matter & Tephra fall & Group 4-1 & $620 \pm 50$ & 1304-1398 cal A.D. \\
\hline GrN-23985 & $\begin{array}{l}\text { Qda. Grande arriba, } \\
\text { tributary }\end{array}$ & Charcoal & Soil in ash & Group 4-1 & $1290 \pm 100$ & 655-865 cal A.D. \\
\hline Lv-2111 & Qda. San Lazaro & Charcoal & Pumice fall & Group 4-1 & $1920 \pm 200$ & 160 cal B.C.- 340 cal A.D. \\
\hline GrN-23149 & Qda. Honda & Charcoal & Pumice fall & Group 4-1 & $2060 \pm 40$ & 106 cal B.C.- 2 cal A.D. \\
\hline GrN-22162 & Qda. Honda & Charcoal & Pumice fall & Group 4-1 & $2090 \pm 40$ & $160-46 \mathrm{cal}$ B.C. \\
\hline GrA-4398 & Qda. Agua Salada & Charcoal & Pumice flo & Group 4-1 & $2300 \pm 60$ & $402-208$ cal B.C. \\
\hline GrN-23964 & Rio Chili valley, Garita B & Charcoal & Ash fall & Group 4-1 & $3800 \pm 50$ & $1991-2465$ cal B.C. \\
\hline GrA-11253 & $\begin{array}{l}\text { El Porvenir,Alto Misti, } \\
\text { Arequipa }\end{array}$ & Charcoal & Surge & Group 4-1 & $4750 \pm 40$ & $3635-3385$ cal B.C. \\
\hline GrN-23963 & Rio Chili valley Garita A & Charcoal & Surge & Group 4-1 & $5200 \pm 80$ & $3822-4220$ cal B.C. \\
\hline GrA-13242 & Qda. Carabaya & Organic matter & Ash flo beneath surge & Group 4-1 & $6390 \pm 50$ & 5465-5317 cal B.C. \\
\hline GrA-11459 & Qda. Honda & Charcoal & Ash flo & Group 4-1 & $8140 \pm 80$ & 7315-7057 cal B.C. \\
\hline GrN-23961 & $\begin{array}{l}\text { El Porvenir,Alto Misti, } \\
\text { Arequipa }\end{array}$ & Charred wood & Pumice flo above surge & Group 3-4 & $11280 \pm 70$ & $11389-11205$ cal B.C. \\
\hline GrN-24114 & $\begin{array}{l}\text { Qda. Honda abajo } \\
\text { Tributary }\end{array}$ & Charcoal & Ash flo & Group 3-4 & $11340 \pm 240$ & 11805-11075 cal B.C. \\
\hline GrN-24038 & Qda. Honda & Charcoal & Tephra fall & Group 3-4 & $11480 \pm 220$ & $11845-11225$ cal B.C. \\
\hline GrN-23658 & Qda. Pastores arriba & Charcoal & Scoria flo & Group 3-4 & $13640 \pm 330$ & \\
\hline GrN-23889 & $\begin{array}{l}\text { Qda. Huarangal } \\
\text { Huarangero }\end{array}$ & Charcoal & Pumice fall & Group 3-3 & $20960 \pm 380 / 360$ & \\
\hline GrN-23247 & Qda. Pastores & Charred wood & Block-and-ash flo & Group 3-3 & $24840 \pm 480$ & \\
\hline GrN-23246 & $\begin{array}{l}\text { Qda. Honda-Grande } \\
\text { confluenc }\end{array}$ & Charcoal & Block-and-ash flo & Group 3-1 & $31200 \pm 1330$ & \\
\hline GrN-24037 & $\begin{array}{l}\text { Qda. Honda-Grande } \\
\text { confluenc }\end{array}$ & Charcoal & Ash flo & Group 3-1 & $>32,000$ & \\
\hline GrN-23659 & Qda. Pastores Tributary & Charcoal & Ash flow & Group 3-1 & $33400 \pm 2800 / 2160$ & \\
\hline GrN-21574 & Qda. Pastores & Organic matter in soil & & Group 3-1 & $33870 \pm 1800 / 1460$ & \\
\hline GrN-24325 & $\begin{array}{l}\text { Qda. Honda- Grande } \\
\text { abajo }\end{array}$ & Organic matter & Ash flo & Group 3-1 & $33900 \pm 3200 / 2300$ & \\
\hline GrN-24113 & Arenales & Charcoal & Ash flo & Group 2-3B & $>38300$ & \\
\hline GrN-23887 & Qda. Huarangal arriba & Charcoal & Block-and-ash flo & Group 2-3B & $39680 \pm 1370 / 1170$ & \\
\hline GrN-23884 & Río Chili, garita & Charcoal & Pumice flo & Group 2-3B & $40200 \pm 820 / 740$ & \\
\hline GrN-23962 & Qda. Agua Salada abajo & Charcoal & Ash flo & Group 2-3A & $43970 \pm 1180 / 1030$ & \\
\hline GrN-22884 & Qda. Agua Salada Abajo & Charcoal & Pumice flo & Group 2-3A & $47350 \pm 2100 / 1700$ & \\
\hline GrN-23890 & $\begin{array}{l}\text { Qda. Agua Salada arriba, } \\
\text { tributary }\end{array}$ & Charcoal & Scoria flo & Group 2-3A & $48640 \pm 2270 / 1770$ & \\
\hline
\end{tabular}

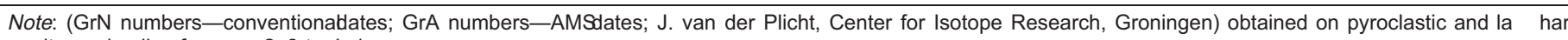
deposits, and soils of groups $2-3$ to $4-1$.

now the Porvenir suburb of Arequipa, $13 \mathrm{~km}$ from the vent. Soils in the tephra pile are poorly developed, even in the wettest altitudinal vegetation belt (3200-3800 masl). Their poor development suggests that explosive activity ceased for only short periods. Wavy ash beds and truncated lenses with small subrounded pumice indicate that runoff and/or eolian processes removed ash deposits of Holocene age. Similar wavy and truncated ash beds toward the top of sections are underlain by $\geq 6400$ yr B.P. primary flo and fall deposits and overlain by a dark soil mixed with a ca. 3800 yr B.P. ash-fall layer in the Río Chili valley (Fig. 8, col. 4; Table 2). Wind action may have been enhanced during the driest Holocene period between ca. 8200 and ca. 3600 yr B.P., evidenced in the area of Lake Titicaca, $150 \mathrm{~km}$ east of Misti (Seltzer et al., 1998).

The dry middle Holocene interval contrasts with the late glacial and early Holocene periods when debris-flo and stream-flo depos- its formed the two volcaniclastic fans upon which the city of Arequipa has been built (Fig. 3 ). Runoff and flas flood triggered by rainstorms, common in January-February, cut into the late glacial-early Holocene volcaniclastic deposits dated between ca. 13700 and 8000 yr B.P. that fille the stream channels (LH4 in Fig. 4).

\section{EXPLOSIVE ACTIVITY OVER THE PAST 2300 YR}

The Most Recent Sub-Plinian Episode, ca. 2300-2050 yr B.P.

Pumice-flo and fall deposits of the last major explosive episode of El Misti are portrayed in Figure 12. We determined two calibrated ca. $2300 \mathrm{yr}$ B.P. ${ }^{14} \mathrm{C}$ ages at the base of pumice-flo deposits in Quebrada Agua Salada and three ca. 2050 yr B.P. ages at the base of pumice-fall deposits in Quebrada San La- zaro (Thouret et al., 1995; Table 2). Whether the error range in ${ }^{14} \mathrm{C}$ ages encompasses one or a few discrete eruptions is not yet established.

A pumice-fall deposit dispersed $\geq 25 \mathrm{~km}$ southwest toward Arequipa includes three layers, totaling $30 \mathrm{~cm}$ thick, $13 \mathrm{~km}$ southwest of the vent. Accidental lithic and accessory oxidized fragments of the upper coarse sand layer are more abundant than in the lower layer, which is rich in coarse pumice lapilli. The banded pumice includes layers of rhyolite $\left(71 \% \mathrm{SiO}_{2}\right)$ and andesite $\left(63 \% \mathrm{SiO}_{2}\right)$ composition. A thin, interbedded, middle layer of coarse sand, and nonvesicular lithic fragments indicates that the eruption column dwindled just before the second layer was emplaced, probably owing to erosion of the conduit. From the isopachs of the pumice-fall deposit, bulk volume amounts to $\sim 0.1 \mathrm{~km}^{3}$ (Fig. 12) . From the isopleths in Figure 12, the height of 


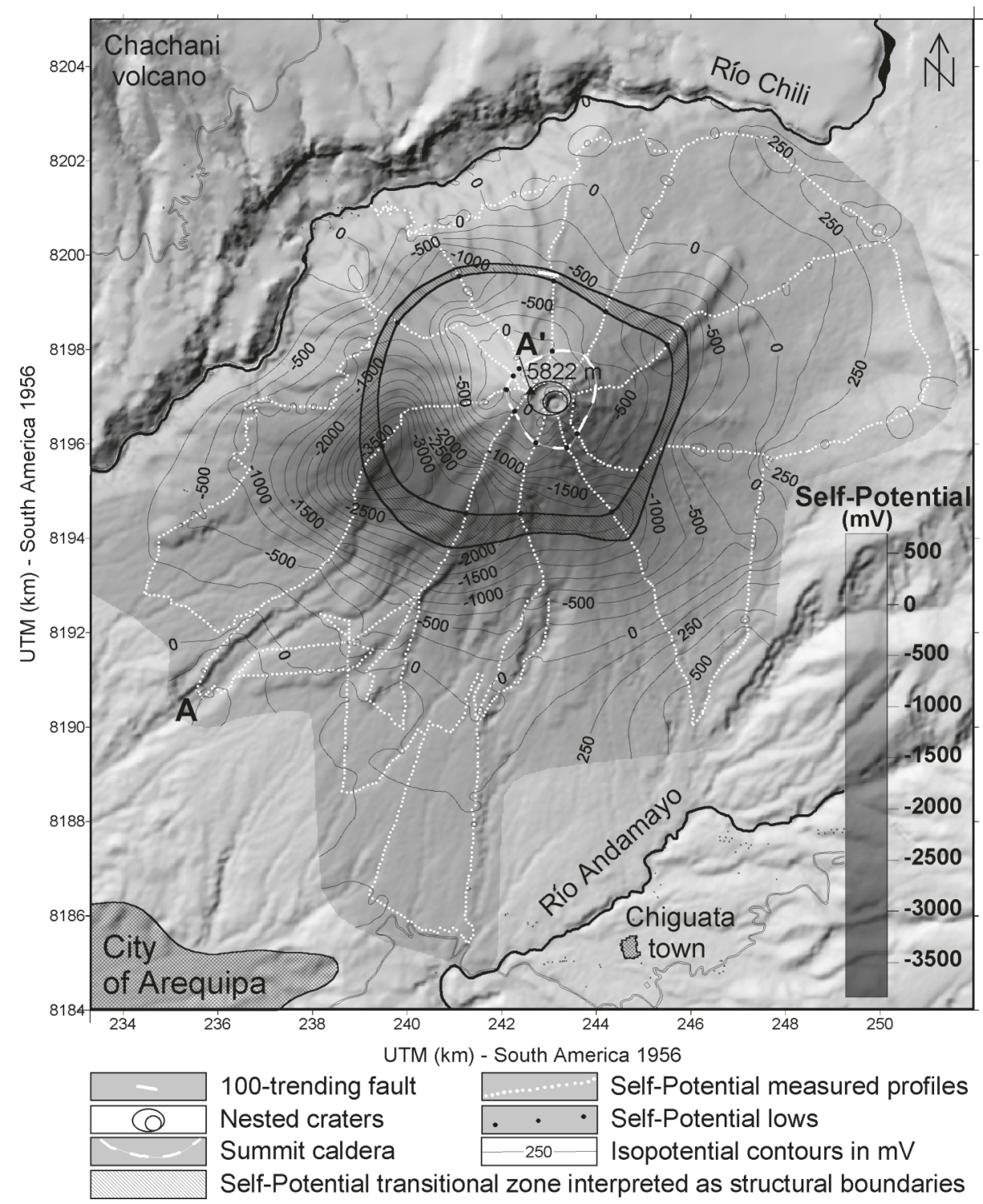

Figure 9. Self-potential map superimposed on a DEM of EI Misti volcano. The A-A' profil is shown in Figure 10.

the sub-Plinian column was in the range of $10-13 \mathrm{~km}$ above the vent.

Nonwelded pumice-rich flow with a volume of $\leq 0.7 \mathrm{~km}^{3}$ were channeled in all radial valleys as far as the present suburbs of Arequipa and $2 \mathrm{~km}$ upstream from the town of Chiguata (PF4 in Fig. 4; Fig. 8, col. 1; Fig. 11C). No fall deposit underlies the voluminous flo deposits in the south catchments (Quebrada Agua Salada, Fig. 8, col. 5). However, several open-work pumice lenses interbedded with 4 to 6 flo units suggest that the eruption column collapsed on the south flan during the tephra fall. At $\sim 3400$ masl, the 30 m-thick pyroclastic-flo deposits are pumicerich, whereas the uppermost unit is rich in ice-rich flow were rapidly transformed into lahars immediately after the eruption. The ca. 2300-2050 yr B.P. explosive episode may have also destabilized the steep, fractured west-northwest flank as suggested by rockslide avalanche and lahar deposits rich in oxidized and scoriaceous blocks that form terraces of similar age in the upper Río Chili canyon (RA4 in Fig. 4).

\section{Moderate Explosive Activity in Historic Time}

Eruptions were not recorded until the founding of Arequipa in 1540 by the Spanish. However, youthful pyroclastic deposits, widespread on the north, south, and southeast flank of the volcano toward the town of Chiguata (HT4 in Fig. 4; Fig. 8, cols. 1 and 4), record a few historical eruptions younger than 2050 yr B.P.

Youthful ash-rich flo deposits form two prominent fronts at $\sim 3800$ and 3400 masl on the southeast flan of Misti. A gray ash-rich flo deposit $4 \mathrm{~m}$ thick shows dune-like landforms as far as $9 \mathrm{~km}$ south of the vent near Quebrada Honda-Grande (3200 masl). Charcoal in soil beneath the ash-flo deposit in this area yielded a ${ }^{14} \mathrm{C}$ age of ca. 1300 yr B.P. (Table 2). However, the small volume of tephra-fall deposits indicates that explosive activity was mild. An ash layer interbedded in a block-and-ash-flo deposit on the south flan (Quebrada Huarangal, 3800 masl) is dated at ca. 620 yr B.P. (Table 2).

A scoriaceous ash-fall layer of andesitic composition is at least as thick as $10 \mathrm{~cm}$ on the cone slopes and $2-4 \mathrm{~cm}$ in the Arequipa area (Fig. 12). A black ash layer beneath the A.D. 1600 Huaynaputina ash (Thouret et al., 1999b) records the A.D. 1440-1470 eruptive event, as referred to in anecdotal narrations (Chávez Chávez, 1992). Complaints of the distressed population were such that the Inca emperor, Pachacútec, sent his wife to help the people of Chiguata. A fine-san ash is $1 \mathrm{~cm}$ thick $30 \mathrm{~km}$ west and $20 \mathrm{~km}$ north of the volcano and $0.5 \mathrm{~cm}$ thick $25 \mathrm{~km}$ east in Laguna (Lake) Salinas (Fig. 1; Juvigné et al., 1997). The dispersal lobe (Fig. 12) and the thickest scoria fall on opposite crater rims (Fig. 11A) indicate that discrete Vulcanian eruptions occurred when winds were blowing east-northeast and west-southwest. Both the lack of ballistic scoria or lithic blocks and the sand size of the ash-fall deposit outside the crater area suggest that the eruptive columns were low. The irregular thickness of the thin ash layers and the amount of small xenolithic fragments from the underlying soil and overlying Huaynaputina ash indicate that runoff and wind 


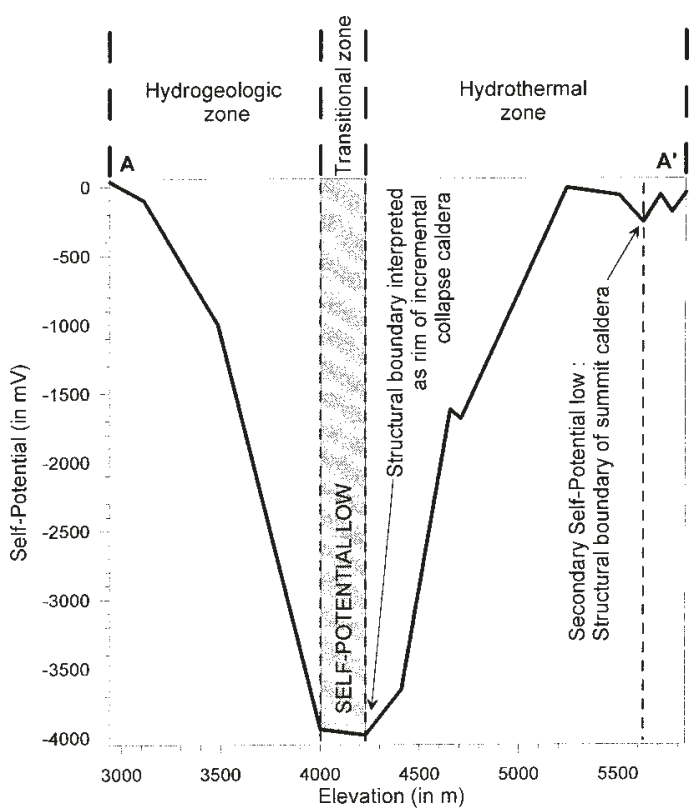

Figure 10. Composite cross section of the measured self-potential profile showing selfpotential versus elevation. The boundaries of the hydrogeologic and hydrothermal zones and profil $\mathbf{A}-\mathrm{A}^{\prime}$ are shown in the accompanying map (Fig. 9).

have mixed the black ash with surficia deposits between small-scale Vulcanian events.

Historic eruptions of Misti may be indirectly recorded as two matrix-supported lahar deposits mantling the middle and lower terraces of the Río Chili in the city of Arequipa. Silt- and sand-sized deposits $1-3 \mathrm{~m}$ thick that include ash and oxidized pyroclastic fragments have been dated at ca. 520 yr B.P. (A.D. 1407-1428 [calibrated ${ }^{14} \mathrm{C}$ date]) and ca. 340 yr B.P. (A.D. $1488-1633$ [calibrated ${ }^{14} \mathrm{C}$ date], Table 2). Although the link with the events of A.D. 1400-1600 cannot be demonstrated, the A.D. 1440-1470 eruption may have triggered lahars, as ash has been incorporated in the matrix-supported debris-flo deposits with a volume of $1.5-3 \times 10^{6} \mathrm{~m}^{3}$.

After the Spanish conquest, the record of volcanic activity at Misti mentions several questionable events: 1542?, 1599?, August 1826?, August 1830 and 1831?, September 1869, and March 1870? (Hantke and Parodi, 1966; Simkin and Siebert, 1994). Available narrations (Zamácola y Jaureguí, 1804; Barriga, 1951; Chávez Chávez, 1992) suggest that these events were episodes of increased fumarolic activity. However, three seismic and possibly phreatic events occurred on 2 May 1677, 9 July 1784, and 28 July and 10 October 1787 (VEI 2? [VEI-volcaniexplosivity index], Simkin and Siebert, 1994). Since 1787, persistent high-temperature fumaroles have been observed on the plug and on the summit's southeast flank Fumaroles high above the crater rim were seen from Arequipa in 1948-1949 and in 1984-1985; the maximum fumarole temperature of the plug was $220^{\circ} \mathrm{C}$, measured in December 1997.

\section{DISCUSSION}

Stratigraphy and preliminary petrologic data support the following discussion on the nature and evolution of lavas and tephras and on the volume versus time relationships for the Misti cones.

\section{Geochemistry}

El Misti's magmas have been geochemically homogeneous, but the products of Misti 4 are distinct, as discussed subsequently. From the relatively homogeneous magmas erupted through time, four rock types prevail: two-pyroxene and amphibole andesites, amphibole dacites, amphibole and biotite dacites, and biotite-bearing rhyolites. Some andesites also bear apatite, and scarce andesites bear one pyroxene or amphibole only, but basaltic andesites are lacking. Lavas from Misti 2 and Misti 3 show no significan change in composition compared to lavas of Misti 1. Most of the calc-alkalic lavas belong to moderately high $\mathrm{K}_{2} \mathrm{O}$ andesites $\left(57.4 \%-62.1 \% \mathrm{SiO}_{2}\right)$, dacites $\left(63.5 \%-66.3 \% \mathrm{SiO}_{2}\right)$, and a few rhyolites (71.7\%-72.8\% $\mathrm{SiO}_{2}$; Fig. 13, after Legendre, 1999). Bulk-rock chemical analyses indicate that the magmas of Misti 2 to Misti 4 have evolved from silica rich to less silica rich through time. In contrast, group 2-2 consists of rhyolites, although they are not unknown in more recent groups.

The mineral suites of the lavas show a trend from group 2-1 toward group 4-1 (Data Repository, after Legendre, 1999). The plagioclase remains similar from group $2-1$ to group 4-1 (except in the rhyolites of group 2-2) and shows a wide range of composition $\left(\mathrm{An}_{23}-\right.$ $\mathrm{An}_{73}$ ) and strong geochemical variations. Clinopyroxene remains relatively constant $\left(\mathrm{En}_{45}-\right.$ $\left.\mathrm{En}_{50}\right)$, but orthopyroxene $\left(\mathrm{En}_{65}-\mathrm{En}_{80}\right)$ and calcic amphibole (pargasite, Fe-pargasite, and Fe-pargasitic hornblende) become more magnesian from group 2-1 toward group 4-1. In the contrasting group 4-1, orthopyroxene disappears whereas ilmenite $\left(\mathrm{TiO}_{2} 44 \%-50 \%\right)$ appears, and magnetite $\left(\mathrm{Fe}_{2} \mathrm{O}_{3} \quad 30 \%-40 \%\right)$ plots closer to the pure-magnetite pole. Geothermobarometers indicate the order of crystal formation (clinopyroxene, orthopyroxene, then amphibole and plagioclase) and relatively homogeneous equilibrium conditions for minerals of groups 2-1 to 3-2. However, lavas of group 4-1 reflec weaker $f\left(\mathrm{O}_{2}\right)$ and less oxidizing conditions than those of the previous groups. On the basis of the equilibrium conditions indicated by the mineral phases, Legendre (1999) suggested a magma chamber depth in the range of 3-9 km. The comparison of data from stratigraphy and geochemistry leads to four results (Legendre, 1999):

1. Abundant andesites coincide with the emplacement of lava flow and/or moderate volumes of tephra that formed groups 2-1, 3 3 , and 4-1. Abundant dacites and rhyolites coincide with large-scale explosive eruptions that emplaced groups $2-2,2-3,3-1$, and 3-2 and may have led to an incremental caldera collapse.

2. Groups $2-1$ and $2-2$ may belong to a similar eruptive period with a differentiation from andesites to rhyolites. Rhyolites seem to be related to large explosive eruptions toward the end of Misti 2.

3. Andesites of groups $2-1$ to $3-2$ are similar in their mineral assemblages and geochemistry and may have formed through AFC (assimilation-fractional crystallization) in the lowermost crust. In contrast, rhyolites of group 2-2 and dacites of groups 2-2 and 3-1 may be the result of fractionation and contamination in the upper crust.

4. The lack of orthopyroxene and the presence of ilmenite in group 4-1 constitute a distinct mineral suite. This difference may reflec a change in physical conditions in the reservoir. Trace-element geochemistry (Jacquemin 

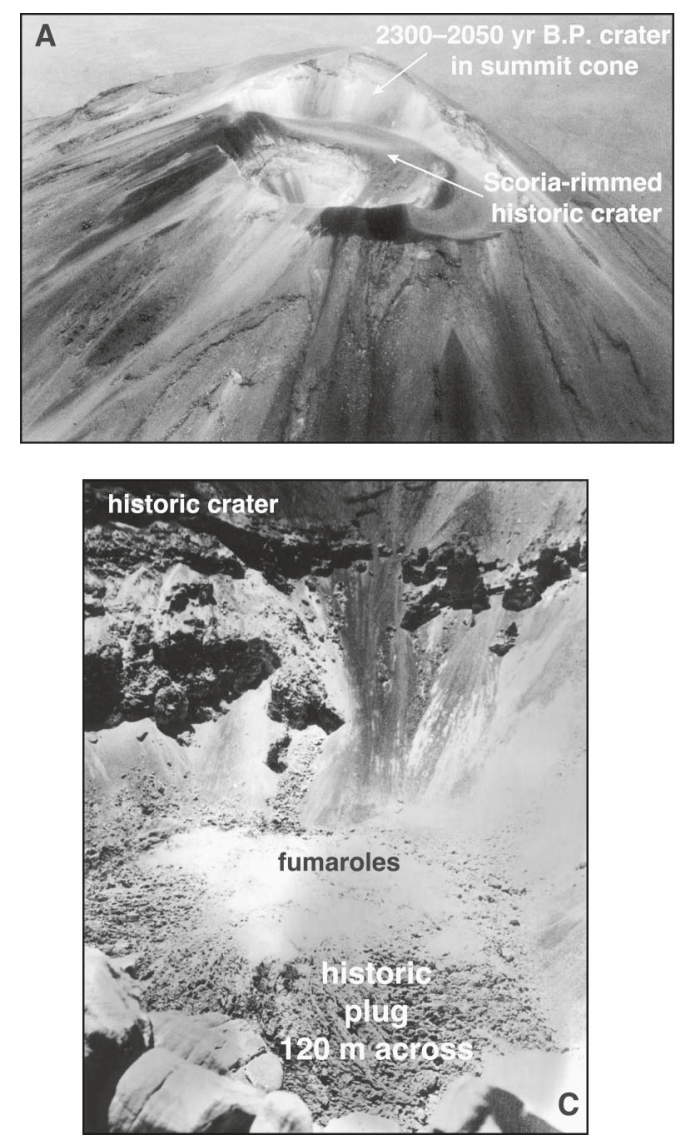

Figure 11. (A) Summit cone of Misti 4 (looking north): the historic, scoria-rimmed crater nested in a crater $950 \mathrm{~m}$ across, probably ca. 2300-2050 yr B.P. (B) Pumice-flo deposits 20-30 $\mathrm{m}$ thick, channeled $>9 \mathrm{~km}$ in the Quebrada (Qda.) San Lazaro valley and dated at ca. 2300-2050 yr B.P. (C) Fumarolic plug in historic, scoria-rimmed crater $200 \mathrm{~m}$ deep.

and Joron, 1984) indicates a new andesitic magma batch.

\section{Volume Versus Time Relationships in the Composite Misti 2-4 Stratocones}

The eruption rate over the $\sim 112-\mathrm{k} . \mathrm{y}$.-long period of the Misti 2-4 stratocones (preserved volume of $70-83 \mathrm{~km}^{3}$ ) averaged $0.63 \mathrm{~km}^{3} /$ k.y., but four periods of peak eruption rates (accountable for groups 2-1, 2-2, 3-2, and 33) may have increased the cone volumes by as much as $2.1 \mathrm{~km}^{3} / \mathrm{k} . \mathrm{y}$. (Fig. 14). Between emplacement of groups $2-2$ and $3-1$ and between emplacement of groups 3-3 and 4-1, the Misti 2 and 3 cones underwent erosion. Sustained explosive periods $2-3,3-1,3-3$, and $4-1$ have produced as much as $7-10 \mathrm{~km}^{3}$ of ignimbrites and tephra, preserved around the volcano. The amount of deposits removed from each cone and the duration of erosion intervals are not accurately known at Misti. Thus, our estimate of the growth rates of Misti 2, Misti 3, and Misti 4 cones is considered a

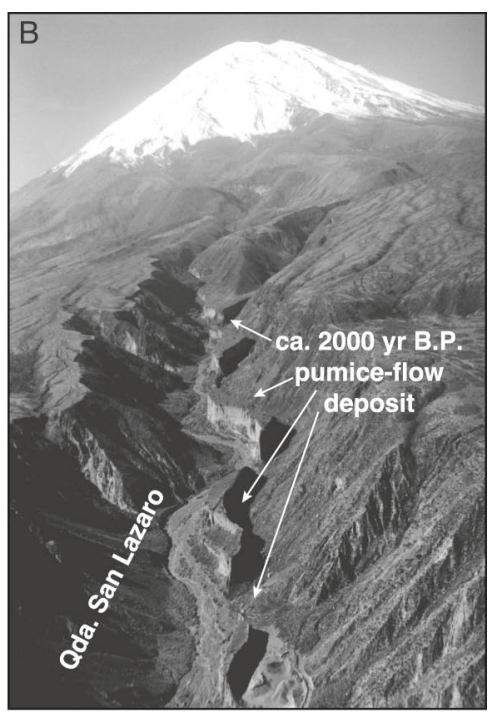

phreatic events reportedly occurred in 1677 , 1784, and 1787.

2. Seven eruptive periods have successively built up Misti 2-4 during a period of $\sim 112$ k.y. The eruption rate over that period averaged $0.63 \mathrm{~km}^{3} / \mathrm{k} . \mathrm{y}$.

3. Repeated episodes of growth and destruction of lava domes have triggered domecollapse avalanches and block-and-ash flows including pyroclastic surges (e.g., group 3-2, ca. 31000 and 25000 yr B.P., and group 33, ca. 25000 and 20000 yr B.P.). The domebuilding episodes alternated with sub-Plinian eruptions whose high columns collapsed and generated pyroclastic flow (e.g., groups 3-1, $3-3$, and 4-1).

4. Nonwelded dacitic ignimbrites (groups 2-3 and 3-4) with a bulk volume of 4-6.5 $\mathrm{km}^{3}$ probably reflec large explosive eruptions that may have led to an incremental caldera collapse or formation of large craters between ca. 50000 and $40000 \mathrm{yr}$ B.P. and again to a summit caldera between ca. 13700 and 11 300 yr B.P.

5. Misti 4 erupted less evolved andesites with a distinct mineral suite, compared to that of Misti 2 and Misti 3. Scoria-flo and fall deposits of Misti 4 are related to the formation of the summit caldera at ca. $13700-11300 \mathrm{yr}$ B.P., the nested craters, and the A.D. 14401470 event. A decrease in $\mathrm{SiO}_{2}$ content in the products of group 4-1 indicates injection of a new andesite magma batch, but the ca. 2050 yr B.P. banded pumice of rhyolitic and andesitic composition suggests a process of magma mixing in a reservoir at a depth of 3-9 km.

6. Sustained explosive eruptions have delivered at least 12 pumice falls during the past ca. 50000 yr. Sub-Plinian pumice falls occurred every 2000 to 4000 yr on average, and ash falls occurred every 500 to $1500 \mathrm{yr}$ on average. The last sub-Plinian explosive episode was at ca. 2300-2050 yr B.P.; it released pumice fall and flow $\leq 0.7 \mathrm{~km}^{3}$ in volume. The last small events were at A.D. 1440-1470 and produced a volume of $\leq 6 \times 10^{6} \mathrm{~m}^{3}$ of ash fall. Lahars swept down the Río Chili valley and tributaries as recently as in the 1600 s. Persistent, high-temperature fumarolic activity is observed today on the plug and on the summit's southeast flank

Thus, considerable hazards remain at Arequipa and Chiguata, where 750000 people may be affected at least indirectly by (1) thick tephra-fall deposits that could cover the city and its airport, (2) pyroclastic flow and surges that could affect the city suburbs $13 \mathrm{~km}$ away from the vent, and (3) debris flow and flas flood induced by rainstorms and snowmelt, as well as rockslide avalanches that 


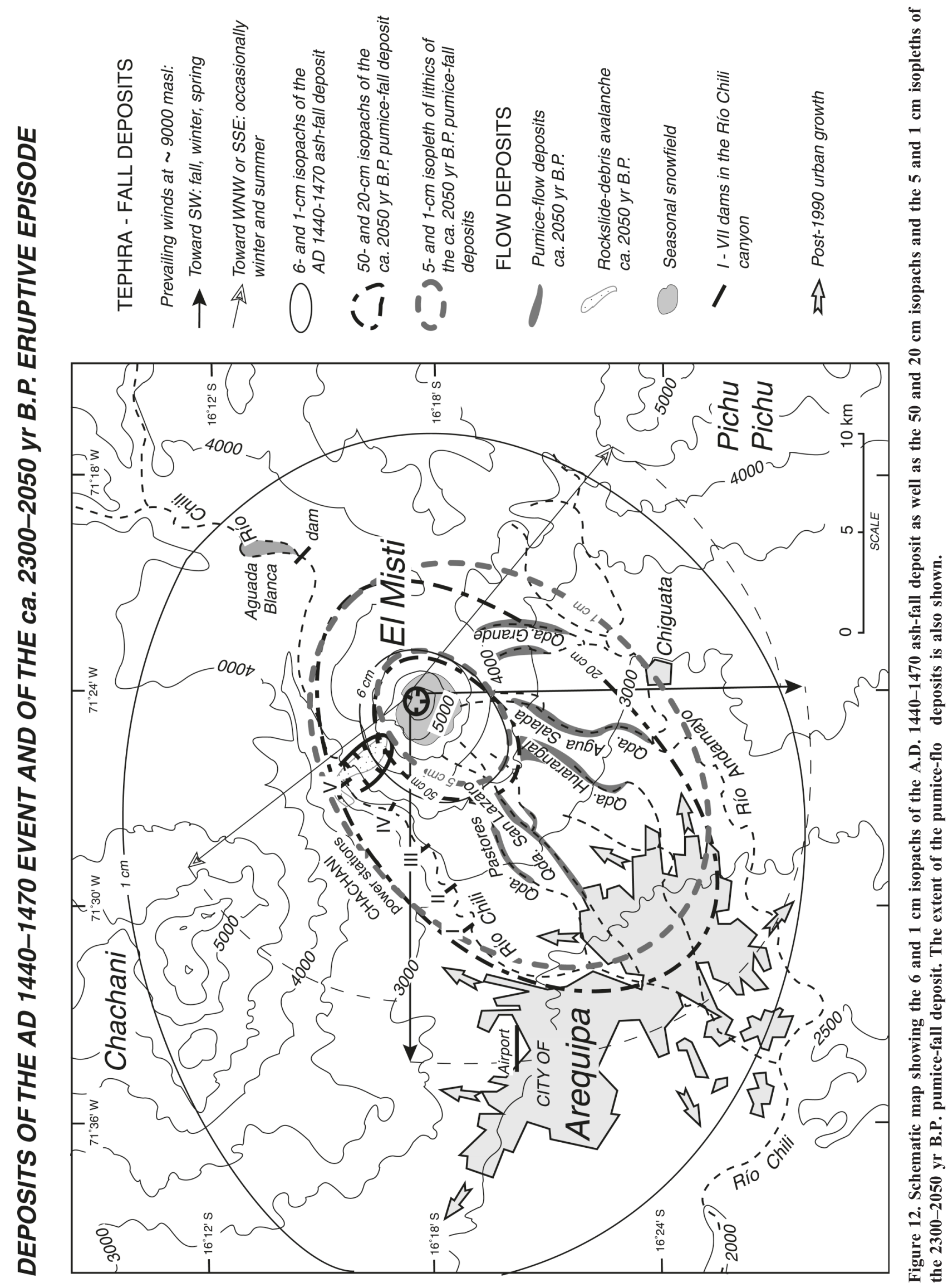




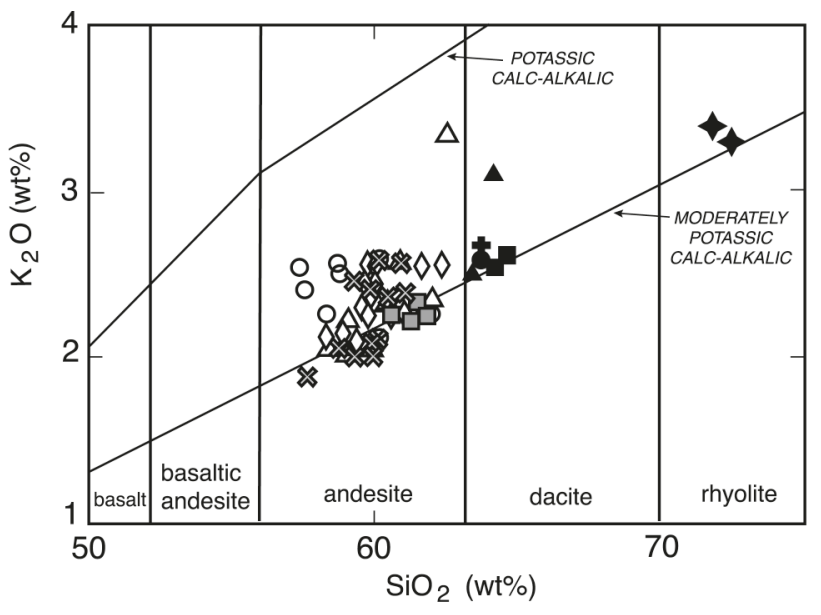

$\aleph$ andesite of group 4-1 ( $\geq 14 \mathrm{ka}$ )

$\diamond$ andesite of group 3-2 (30-25 ka)

< rhyolite of group 2-2 (70-50 ka)

$\triangle$ dacite of group 2-1 (110-70 ka)

dacite of group 3-1 (36-31 ka)

$\triangle$ andesite of group 2-1 (110-70 ka)

dacite of group 2-3 (50-40 ka)

$\square$ andesite of group 2-3 (50-40 ka)

- Misti 1 dacite

Misti 1 andesite

Figure 13. $\mathrm{K}_{2} \mathrm{O}$ vs. $\mathrm{SiO}_{2}$ plot showing the composition of rocks of the groups 2-1 to 4-1 of Misti 2-4 (after Legendre, 1999).

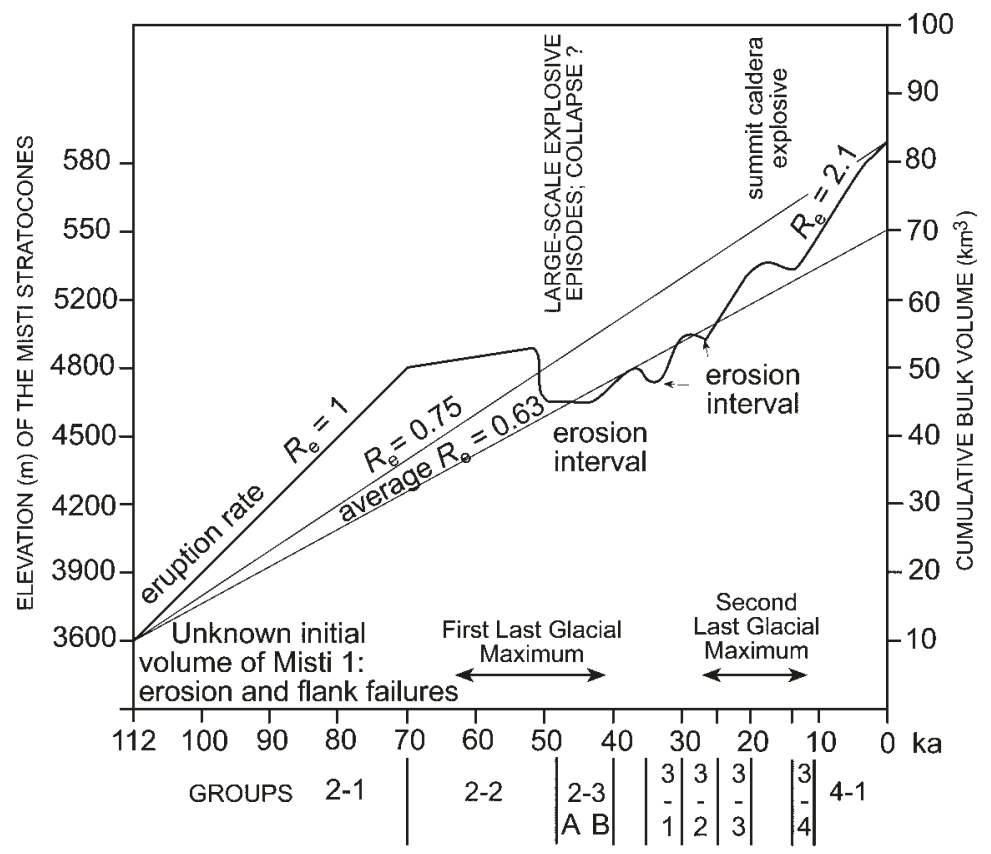

Figure 14. Schematic cumulative eruption volume vs. time for the Misti stratocones 2-4 based on maximum $\left(\sim 83 \mathrm{~km}^{3}\right)$ and minimum $\left(\sim 70 \mathrm{~km}^{3}\right)$ volumes and on edific elevation during the 112-k.y.-long eruptive period. (Volumes are based on the equation 1/3 $r^{2} h$, where $h=2.2 \mathrm{~km}$ and $r=6-5.5 \mathrm{~km}$.) Minimum and maximum cumulative eruption rates in $\mathbf{k m}^{3} / \mathbf{k} . \mathbf{y}$. and reconstructed curve of growth of the stratocones are also drawn.

could damage the valleys of Río Chili and tributaries.

The possible impact of Misti on Arequipa is as worrisome as that of Vesuvius near Napoli. Poor, densely populated suburbs have spread upstream beyond the 1991 city boundary toward the volcano and the town of Chiguata, the areas most affected by El Misti in recent history (Fig. 12). The lack of emergency-response policy and the lack of land-use planning prevent decision makers from regulating city growth. Future growth of the city should be preferentially oriented southeast and west of the depression but beyond $25 \mathrm{~km}$ from the vent.

\section{ACKNOWLEDGMENTS}

This research has been supported by the Institut de Recherche pour le Développement during a cooperative research project with the Instituto Geofísico del Perú (IGP) and UMR 6524-CNRS, Université Blaise-Pascal, Clermont-Ferrand. We appreciate the support of IGP (R. Woodman, H. Montes) and Civil Defense in Arequipa (A. Arguedas). We thank J.-Ph. Eissen, O. Macedo, Ch. Legendre, P. Navarro, M. Rivera, J. Dávila, D. Ramos, and R. Gusset for help in fiel and laboratory. We are indebted to $\mathrm{J}$. Hunt, F. Chambers, and G. Williams-Jones for improving drafts and to R. Waitt and S. de Silva for insightful comments.

\section{REFERENCES CITED}

Barker, S.D., 1996, El sillar ocioso: Bulletin of Volcanology, v. 58 , p. $317-318$.

Barriga, V.M., 1951, Los terremotos en Arequipa (15821868): Arequipa, La Colmena, 426 p.

Chávez Chávez, J.A., 1992, La erupción del volcán Misti, Pasado, presente, futuro: Arequipa, Impresiones Zenit, $158 \mathrm{p}$.

Davidson, J., and de Silva, S., 2000, Composite volcanoes, in Sigurdsson, H., et al., eds., Encyclopedia of volcanoes: San Diego, Academic Press, 1417 p.

de Silva, S.L., and Francis, P.W., 1991, Volcanoes of the Central Andes: Berlin, Springer, 216 p.

García-Zuñiga, F.F., and Parrot, J.F., 1998, Analyse tomomorphométrique d'un édific volcanique récent: Misti, Pérou: Paris, Comptes Rendus de l'Académie des Sciences, Sér IIa, v. 327, p. 457-462 (with abridged English version)

Glicken, H.X., 1991, Facies architecture of large volcanicdebris avalanches: Sedimentation in volcanic settings, in Fisher, R.V., and Smith, G.A., eds., Sedimentation in volcanic settings: SEPM (Society for Sedimentary Geology) Special Publication 45, p. 99-106.

Hantke, G., and Parodi, A., 1966, Catalogue of the active volcanoes of the world. Part XIX: Colombia, Ecuador and Peru: Naples, IAVCEI, $73 \mathrm{p}$.

INEI-ORSTOM, 1998, El Perú en Mapas, Atlas en base al censo de población y vivienda: Lima, Institut de Recherche pour le Développement, $140 \mathrm{p}$.

Jackson, D.B., and Kauahikaua, J., 1987, Regional selfpotential anomalies at Kilauea volcano, in Decker, R.W., Wright, T.L., and Stauffer, P.H., eds., Volcanism in Hawaii: U.S. Geological Survey Professional Paper 1350, p. 947-959.

Jacquemin, H., and Joron, J.L., 1984, Volcanologie et magmatologie du volcan calco-alcalin El Misti: Paris, Société Géologique de France, Résumé, Tenth Réunion Annuelle des Sciences de la Terre, Bordeaux, p. 300.

Juvigné, E., Thouret, J.-C., Gilot, E., Gourgaud, A., Legros, F., Uribe, M., and Graf, K., 1997, Etude téphrostrati- 
graphique et bioclimatique du Tardiglaciaire et de l'Holocène de la Laguna Salinas, Pérou méridional: Géographie Physique et Quaternaire, v. 51, p. 219-231.

Kaneoka, I., and Guevara, C., 1984, K-Ar age determinations of late-Tertiary and Quaternary Andean volcanic rocks, southern Peru: Geochemical Journal, v. 18, p. 233-239.

Lefèvre, C., 1979, Un exemple de volcanisme de marge active dans les Andes du Pérou (sud) du Miocène à l'actuel [Ph.D. thesis]: Montpellier, Université Sciences et Techniques du Languedoc, 555 p.

Legendre, C., 1999, Pétrogenèse du volcan "Misti moderne" (Sud Pérou): Essai de caractérisation de l'évolution pétro-géochimique et chronologique: Cergy-Pontoise, Institut de Géologie A Lapparent, Rapport stage fi d'étude, $88 \mathrm{p}+$ annexes.

Legros, F., 1998, Téphrostratigraphie du volcan Misti (Pérou) et modélisation des écoulements pyroclastiques [Ph.D. thesis]: Clermont-Ferrand, France, Université Blaise-Pascal, $150 \mathrm{p}$.

Macedo, L.F., 1994, Peligro volcánico potencial del Misti [M.Sc. thesis]: Arequipa, Universidad Nacional San Agustín, Convenio DHA-UNDRO-UNSA, 112 p.

Poupeau, G., 1996, in Vatin-Pérignon, N., Poupeau, G., Oliver, R.A., Lavenu, A., Labrin, E., Keller, F., and Bellot-Gurlet, L., 1996, Trace and rare-earth element characteristics of acidic tuffs from southern Peru and northern Bolivia and a fission-trac age for the Sillar of Arequipa: Journal of South American Earth Sciences, v. 9, no. 1-2, p. 91-109.

Seltzer, G.O., 1990, Recent glacial history and paleoclimate of the Peruvian-Bolivian Andes: Quaternary Science Reviews, v. 9, p. 137-152.

Seltzer, G.O., Baker, P., Cross, S., Dunbar, R., and Fritz, S. 1998, High-resolution seismic reflectio profile from Lake Titicaca, Peru-Bolivia: Evidence for Holocene aridity in the tropical Andes: Geology, v. 26 , p. $167-170$.

Simkin, T., and Siebert, L., 1994, Volcanoes of the world (2nd edition): Washington, D.C., Smithsonian Institution, $349 \mathrm{p}$.

Suni, J., 1999, Estudio geológico y vulcanológico del volcán Misti y sus alrededores [Ph.D. thesis]: Arequipa, Universidad Nacional San Agustin, Facultad Geología y Minas, $179 \mathrm{p}$.

Thouret, J.-C., 1999, Assessment of volcanic hazards in the area of Arequipa City, based on the eruptive history of the Misti volcano, southern Peru: Zeitschrift für Geomorphologie, supplement, v. 114, p. 89-112.

Thouret, J.-C., Legros, F., Gourgaud, A., Salas, G., Juvigné, E., Gilot, E., Uribe, M., and Rodriguez, A., 1995, Un exemple de prévision des risques volcaniques au Pérou méridional (région d'Arequipa), fondé sur l'étude de l'activité éruptive récente du strato-volcan El Misti: Paris, Comptes Rendus de l'Académie des Sciences, Sér IIa, v. 320, p. 923-929.

Thouret, J.-C., Suni, J., Eissen, J.-Ph., and Navarro, P., 1999a, Assessment of volcanic hazards in the Are quipa area based on the eruptive history of Misti volcano, southern Peru: Zeitschrift für Geomorphologie, band 114, suppl., p. 89-112.

Thouret, J.-C., Dávila, J., and Eissen, J.-Ph., 1999b, Largest historic explosive eruption in the Andes at Huaynaputina volcano, south Peru: Geology, v. 27, p. $435-438$.

Vatin-Pérignon, N., Poupeau, G., Oliver, R.A., Lavenu, A., Labrin, E., Keller, F., and Bellot-Gurlet, L., 1996, Trace and rare-earth element characteristics of acidic tuffs from southern Peru and northern Bolivia and a fission-trac age for the Sillar of Arequipa: Journal of South American Earth Sciences, v. 9, no. 1-2, p. 91-109.

Zablocki, C.J., 1976, Mapping thermal anomalies on an active volcano by the self-potential method, Kilauea, Hawaii: San Francisco, California, Proceedings, Second U.N. Symposium on the Development and Use of Geothermal Resources, May 1975, v. 2, p. $1299-1309$.

Zamácola y Jaureguí, J.D., 1804, Apuntes para la historia de Arequipa: Primer festival del libro arequipeño: $\mathrm{Ar}$ equipa, Edición 1958, 15 p. 